\title{
Geomorphic and lithologic characteristics of Wadi Feiran basin, southern Sinai, Egypt, using remote sensing and field investigations
}

\author{
Ayman A Ahmed ${ }^{1, *}$, Mohamed Abdelkareem ${ }^{2}$, Asran M Asran $^{1}$ \\ and TAWFig M MAHRAN ${ }^{1}$ \\ ${ }^{1}$ Geology Department, Sohag University, Sohag, Egypt. \\ ${ }^{2}$ Geology Department, South Valley University, Qena 83523, Egypt. \\ *Corresponding author.e-mail: ayman@sohag.edu.eg
}

MS received 29 July 2016; revised 6 April 2017; accepted 6 April 2017; published online 31 August 2017

Wadi Feiran is an important drainage basin in southern Sinai Peninsula covering an area of about $1785 \mathrm{~km}^{2}$, its streams drain into the Gulf of Suez crossing variety of rocks and sedimentary units varied in age from Precambrian to Quaternary. Field investigations, geographic information systems (GIS) and remote sensing studies including Landsat-7 ETM+, Radarsat-1, and SRTM DEM were integrated to reveal its lithologic, geologic and geomorphic features. Besides the field investigations, rock units including basement and pre- and syn-rift sedimentary units were discriminated using band ratios and principal component analysis techniques (PCA). Such techniques revealed that the crystalline rocks covering W. Feiran are unaltered rocks lacking OH-bearing minerals. Radar data successfully displayed the structures and geomorphic features related to topography. Moreover, the techniques allowed the extraction of the dyke-like structures along faults and shear zones. This also characterized the topographic variations through analysis of the shaded terrain and the altitudinal profiles. The results of data integration, lineament analysis and lineament density maps revealed that the structural grain in the present study has four different trends: N20-45E, N30-45W, N-S and E-W. Based on analysis of radar data and geomorphic indices, W. Feiran is an asymmetrical basin, its left side occupies $\sim 34 \%$ of the total area that leads to a supposedly massive tilt towards the south which caused the southwestward slope.

Keywords. Remote sensing; Wadi Feiran; Sinai; Egypt.

\section{Introduction}

The Sinai Peninsula forms a triangular region in northeastern Egypt. The southern Sinai basement complexes are part of the Arabian-Nubian Shield, which covers several countries such as Egypt, Saudi Arabia, Sudan, Eritrea, Ethiopia, and Yemen. The southern portion of the Sinai Peninsula also includes mountains of the Pan-African basement complex. The paleozoic sedimentary rocks cover the northern part of the peninsula (Kabesh et al. 2013). The shield developed is contemporaneous with the Neoproterozoic East African Orogeny of about 900-550 Ma (Be'eri-Shlevin et al. 2009), and is widely viewed as an association of volcanic-arc and ophiolite remnants that were shaped during the assembly of the eastern part of Gondwana (Bentor 1985; Stern 1994, 2002; Stoeser and Frost 2006). The geologic and tectonic setting of the Sinai Peninsula are representing the 
counterpart of the northern Eastern Desert as they are characterized by extensional-related tectonic features which are intruded by intrusive, volcanic, and dyke-like swarms of about 800 and $530 \mathrm{Ma}$ (e.g., Bielski 1982).

Integration of remote sensing data and GIS techniques as well as geologic investigations is an effective means for deciphering the structural features. Remote sensing techniques provided significant information in mapping of the geological structures (e.g., Gupta 2003; Ninomiya et al. 2005; Thurmond et al. 2006; Liu et al. 2013). There are different datasets and approaches to obtain information of the remotely sensed data. Optical and microwave satellite data have been successfully used to:

- detect the sharp geological contacts that are located along structural features (such as fractures, fault zones, fault scarps, joints, and fold axes) (Ramsay and Huber 1987) where these contacts could have revealed a subsurface extension (Sabins 2000),

- mapping lithology (depending on the spectral characteristics of the target, e.g., minerals and rock units) and

- gaining information about surface roughness and illumination effects that are effectively useful to understand the topography, lineaments, geomorphic and structural features, and morphotectonic analysis (e.g., Thurmond et al. 2006).

Several studies have applied the band ratios (Geotz et al. 1983; Jensen 1996; Thurmond et al. 2006; Mia and Fujimitsu 2012), and principal component analysis (PCA) in geologic mapping and mineral exploration (e.g., Tangestani and Moore 2000; Aydal et al. 2007; Liu et al. 2013). Landsat data has also been used in geological studies (Aydal et al. 2007).

Microwaves (radar) have the reliability to reveal information about near-surface features which are masked by dry sand (Roth and Elachi 1975; Schaber et al. 1997; Abdelkareem and El-Baz 2015). Thus, they demonstrated to be an excellent tool for mapping arid areas. The Shuttle Radar Topography Mission (SRTM), Digital Elevation Model (DEM) data provided a fast and inexpensive way to extract geomorphic and morphotectonic features indicated by topography (e.g., Grohmann et al. 2007; Abdelkareem and El-Baz 2016). Analysis of the DEM successfully visualized the topography of W. Feiran basin by using 3D visualization and altitudinal profiles. This is to decipher geological problems related to tectonic uplifts, structures and basin geometry. The DEM is helpful in analysis of the morphotectonic features by extracting topographic profiles, 3D perspective visualization, and geomorphic indices. Furthermore, automatic stream extraction (O'Callaghan and Mark 1984) is useful to generate stream channels which help in extracting lineaments and morphotectonic indices of a drainage basin.

Data integration of radar and optical remote sensing also maximized data extraction by combining data of different resolution and information to get a hybrid image (e.g., Harris et al. 1990; Ehlers et al. 2008; Amarsaikhan et al. 2009, 2010) instead of individual images. This integration would enhance the geomorphic and the structural features (e.g., Thurmond et al. 2006; Amarsaikhan et al. 2009, 2010). However, because the visibleNIR data enhances the lithologic variations, the radar data highlight the geomorphic and geometric properties.

Many studies have been done on and around Wadi Feiran including geology, hydrology, hydrogeology, geomorphology, and geophysics such as the works of Wachs et al. (1979), Kassem (1981), Issar and Gilad (1982), El-Ghawaby et al. (1983), ElRefaei (1984), El-Shamy et al. (1989), El-Rayes (1992), El-Refaei (1992), El Tokhi (1992), ElEtr et al. (1993), Ghodeif (1995), Hassan (1997), Shendi (1997), Geriesh (1998), Geriesh et al. (2001), Abou El-Magd (2003), El-Shafei and Kusky (2003), Shendi and Abouelmagd (2004), Gaber et al. (2009), Sultan et al. (2009), Abu-Alam (2010), Massoud et al. (2010), El-Sayed et al. (2012), Kabesh et al. (2013), Seleem (2013), Alrikabi et al. (2015), Mohamed et al. (2015), and Arnos (2016). Majority of these studies focused on hydrology, groundwater and geophysics. Few of these studies were conducted with geomorphic and lithologic mapping using satellite data and not dealt enough with the structural and the morphotectonic features.

In fact, this basin is located in the western part of Sinai that has experienced tectonic deformation during the rifting events of the Red Sea. Noteworthy, the highest point in Sinai is located in the upstream of the studied basin (St. Katherine) which probably initiated in association with the general uplift in Egypt since $~ 30 \mathrm{Ma}$ (Meshref 1990; Burke 1996). This uplift was probably responsible for most of the structural and geomorphic features that shaped the area as the dynamic evolution of Red Sea and tectonic uplift accompanied 
by doming and extensional regime. The rift event of the Red Sea controlled by NW to NNWoriented faults, and the N30-45W trend is the most prominent structural feature that shaped the main stream of the basin. The aforementioned trend is cut by the NE-SW trend which controls the downstream of Wadi Feiran. Structural movements often led to deformation and hydrothermal alterations of the rock units. There is no previous evidence that revealed whether these trends were associated with alteration zones or not. To emphasize that, three sensors such as Landsat-7 ETM+, SRTM, and Radarsat-1 will be used to present evidence of mode of formation of the studied basin and answer the questions: is Wadi Feiran shaped by the tectonic uplift? and what is the relationship between the basin and surrounding terrains?; is any effect of hydrothermal associated with the structural deformations? Therefore, the objectives of this paper are to (1) characterize the structural and lithologic characteristics, (2) identify whether the structural elements are accompanied by hydrothermal solutions or not; and (3) determine the geomorphic and morphotectonic features based on topographic indices.

\section{Geological setting}

The Sinai Peninsula represents an important area of Egypt where it consists of a triangular portion in northeastern Egypt (figure 1). The area under consideration covers about $1785 \mathrm{~km}^{2}$. It is situated in the southwestern part of Sinai Peninsula, Egypt. It is occupied by two major lithological associations including (1) the infrastructure rocks (comprise gneisses, migmatites and amphibolites) and Pan-African basement complex (comprises island-arc volcano/sedimentary rocks); and (2) the Phanerozoic sedimentary rocks (preand syn-rift sedimentary units) cover the northern and western parts of Sinai. Each of them has its specific lithological and structural characteristics and style of deformations and could be described from the oldest to the youngest as follows:

\subsection{The infrastructure and Pan-African basement complex}

The Feiran-Solaf metamorphic complex (FSMC) of Sinai Peninsula is among the highest grade metamorphic complexes in the Arabian-Nubian Shield (El Tokhi 1992; Abu-Alam 2010; Kabesh et al. 2013). These rocks are represented as a NWtrending gneiss belt that is about $40 \mathrm{~km}$ long and $5-10 \mathrm{~km}$ wide intruded by granitic plutons and dyke swarms of porphyritic granites and dolerites. The overall structure of W. Feiran area is dominated by two symmetrical and plunging anticlines; namely, the Feiran anticline in the northwest and the Solaf anticline in the southeast, separated by a synclinal trough and high angle thrust fault
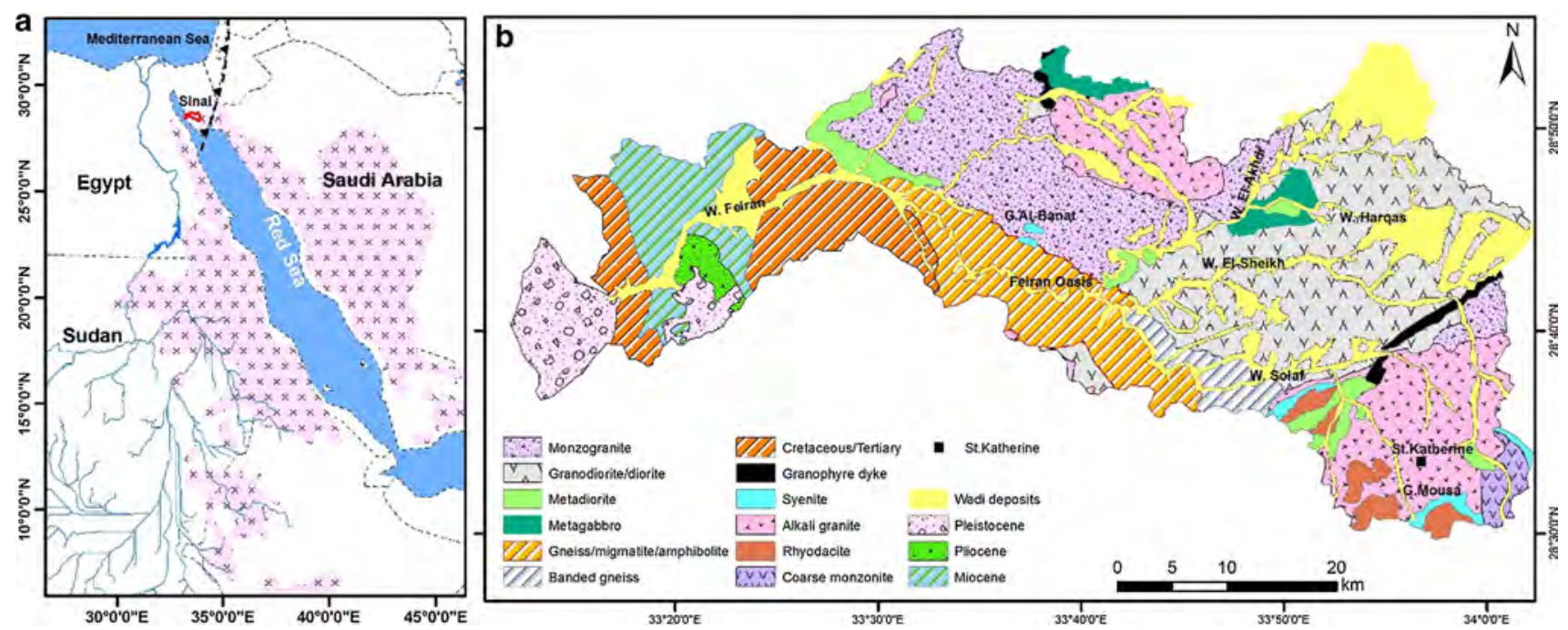

Figure 1. (a) Regional geological setting of the Precambrian basement complex of the Arabo-Nubian Shield along the Red Sea in Egypt, Sudan, Yemen, and Saudi Arabia. Wadi Feiran watershed is marked by red polygon and the stream-networks of the Nile basin in blue colour; (b) Subset of geological map of Sinai Peninsula (GSE 1994) display the rock types and ages of the Phanerozoic in the downstream and the Precambrian rocks in the upstream. 

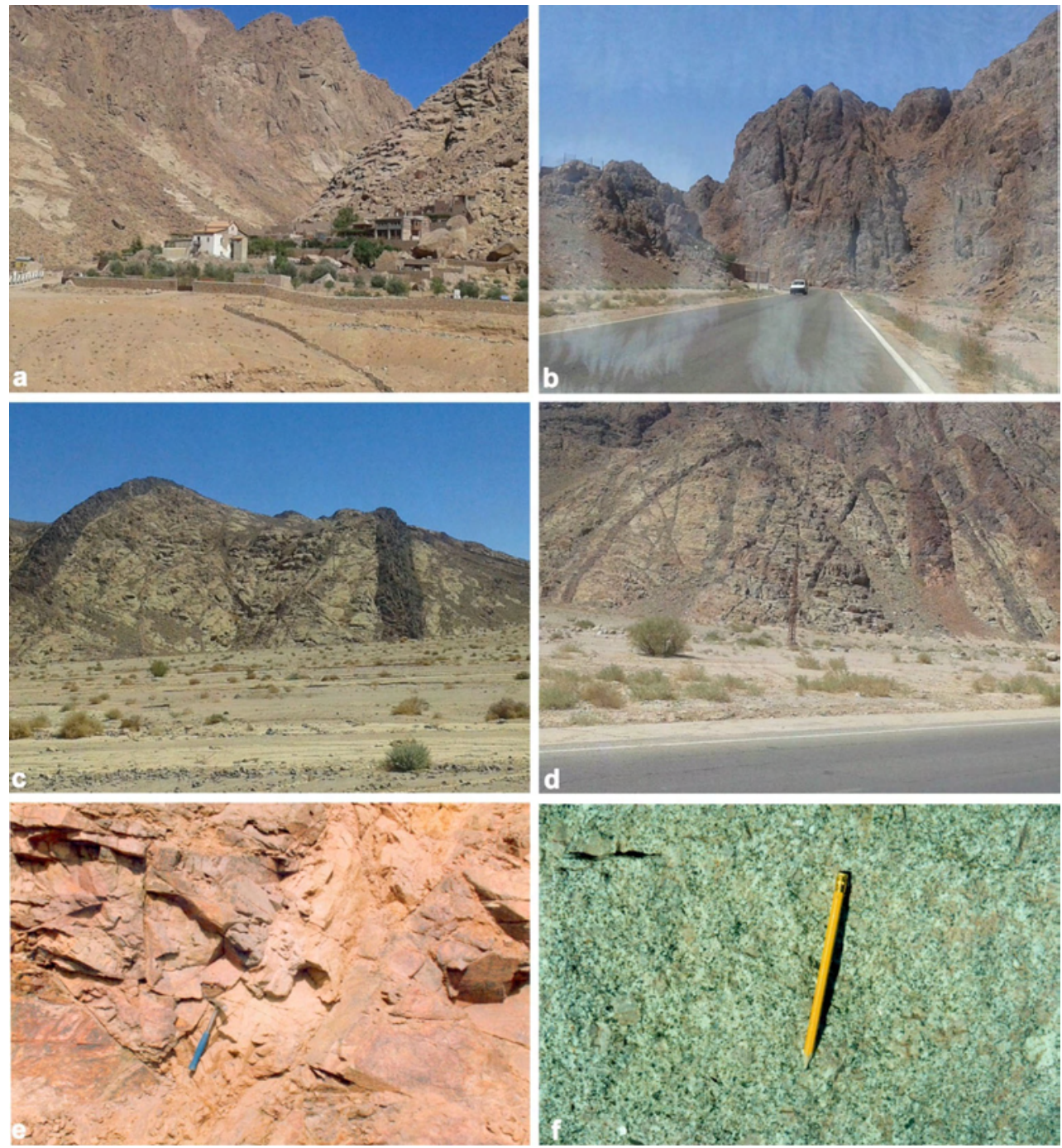

Figure 2. (a) Granite (left) and gneiss (right) along a fault contact; (b) younger granite at W. Feiran; (c) dykes with variable thickness in granite; (d) dyke swarms in granite; and $(\mathbf{e}, \mathbf{f})$ close-up view of granites in W. Feiran basin.

trending approximately $\mathrm{N} 30^{\circ} \mathrm{W}$. The investigated rocks are systematically arranged around these two doubly-plunging antiformal structures (Abu-Alam 2010). The crystalline rocks in the present study include the Feiran zone which situated in the northwest, and Solaf zone in the southeast (figure 1) that were intruded by Pan-African granitoids and dyke swarms (figures 2-5).

\subsubsection{The Feiran zone}

The W. Feiran complex extends in the northwest corner of the exposed crystalline basement rocks in Sinai. The complex includes gneisses, migmatites, and amphibolites. These rocks extend as elongated belts around W. Feiran. The migmatites are characterized by folded structure and display: (a) leucosomes of quartzo-feldspathic composition with minor biotite and hornblende, and (b) hornblende-rich mesosomes containing minor biotite (El Tokhi 1992; Abu-Alam 2010; Kabesh et al. 2013).

\subsubsection{The Solaf zone}

The Solaf zone mostly consists of gneisses and calcsilicate rocks. The granitic-gneisses, and amphibolites are less abundant and occur as small lenses and pockets (figure 3 ). The intrusive granitic rocks are represented by syn- and post-tectonic granites (El Tokhi 1992; Abu-Alam 2010; Kabesh et al. 2013). These intrusions caused deformation for all structural relationships along the boundaries that obtained the structural relationships of the complex. The entire metamorphic and igneous rocks in the present study area are cut by several post dykes of mafic, intermediate and felsic composition (El-Sayed 2006), producing swarms of closely 

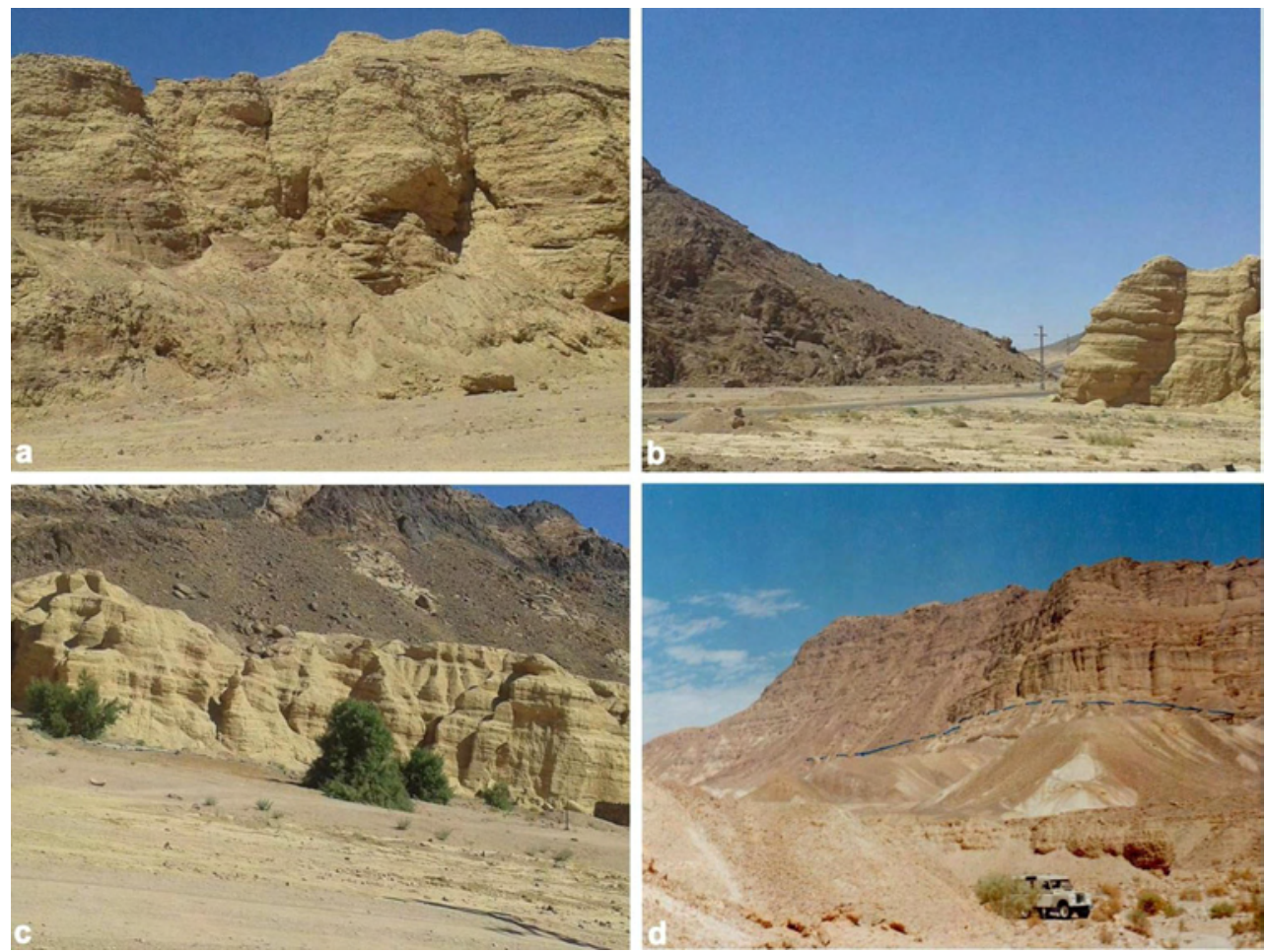

Figure 3. Field view at W. Feiran showing (a) thinly bedded siliciclastic rocks, (b) early pre-rift sequence occurs against granite rocks, (c) sedimentary rocks in contact with Precambrian rocks, and (d) the early syn-rift siliciclastic rocks overlain by late syn-rift carbonate rocks.

parallel sets. They are not equally distributed in the various basement rocks in the study area and have general NE and NW trends.

\subsection{The pre- and syn-rift sedimentary rocks}

The main stream of W. Feiran basin runs across several major tilted fault blocks which are characterized by rhombic shapes, exposed on both sides of the downstream (figure 3). These blocks dip eastward and are contacted in the west by large displacement down to the west normal faults. Towards the eastern margin of the rift, a number of tilted domino-fault blocks called the Feiran tilted blocks, have southwestward dip that are predominated. The exposed pre- and syn-rift rocks at the terminal of W. Feiran, can be divided into four sedimentary sequences that vary in age from Paleozoic to the Quaternary and are as follows (figures 4, 5):

- The Paleozoic-Lower Cretaceous sequence belongs to the early pre-rift stratigraphy of the entrance of W. Feiran and comprises the predominantly non-marine siliciclastic succession (McClay et al. 1998).
- The Late pre-rift Upper Cretaceous-Lower Eocene sequence occurs as isolated, faultbounded grabens and these sediments are divided into two groups; a lower open marine mixed siliciclastics-carbonates and an upper carbonatesdominated sequence.

- The Late Oligocene-Miocene sequence includes the syn-rift sediments which unconformably overlie the Late pre-rift sequence with a major angular unconformity. The earliest syn-rift sediments are dominantly siliciclastics deposited during the initial stage of rifting. The overlying late syn-rift sediments consist of mixed clastics, carbonates and evaporites deposited during rift-climax stage (Mahran et al. 2001).

- The Pliocene-Quaternary sequence comprises the post-rift sediments and is defined by a nonmarine clastics-dominated succession.

\section{Data used and methods}

\subsection{Optical remote sensing}

\subsubsection{Landsat data}

Two scenes of Landsat-7 ETM+ acquired on Dec/22/2000 (p175r040) and Sep/10/2000 


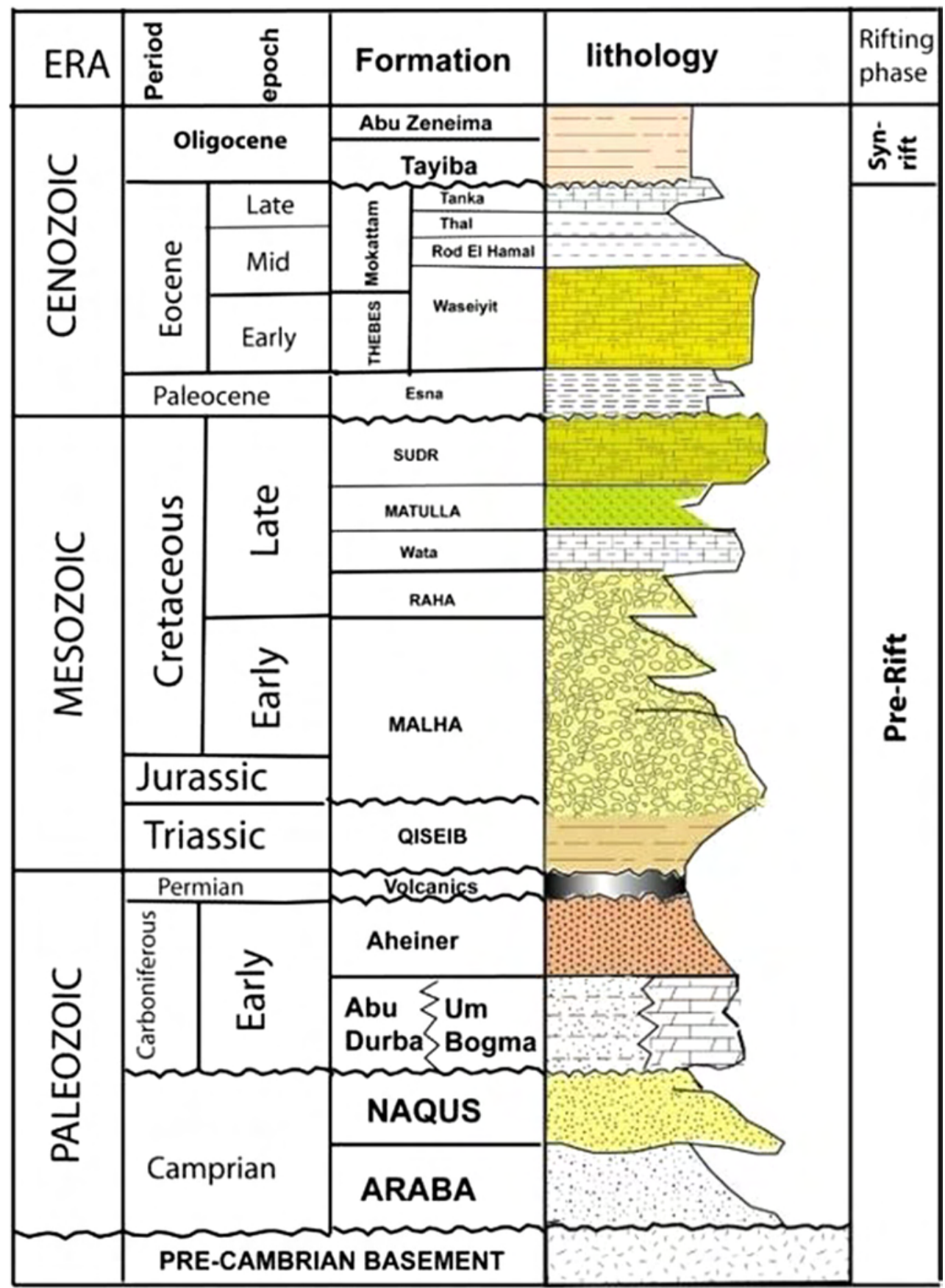

Figure 4. General stratigraphic section of pre-rift rocks at W. Feiran (modified after McClay et al. 1998).

(p174r040) with seven bands (1-5 and 7, 28.5-m resolution) covering the study area were used in the present study. Pre-processing includes radiometric corrections, which the digital numbers (DNs) adapted to Top-Of-Atmosphere (TOA) reflectance (e.g., Liu et al. 2013). Various approaches were tested as the study area has different varieties of sedimentary and basement rocks. Such approaches depend on the spectral reflected properties of the material relative to their surroundings
(Thurmond et al. 2006). Bands 5, 3, and 1 displayed in R, G, and B render the best colour contrast that discriminate geologic units. Moreover, the band ratios 5/7,5/4 and 3/1 (Chica-Olma 2002) in R, G, and B were applied. In addition to band ratios, the principal component analysis (PCA) and Crosta techniques were utilized to investigate the rock units of the study area. Contrast stretching method was also applied to provide better visual interpretation. In a PCA, the statistic 


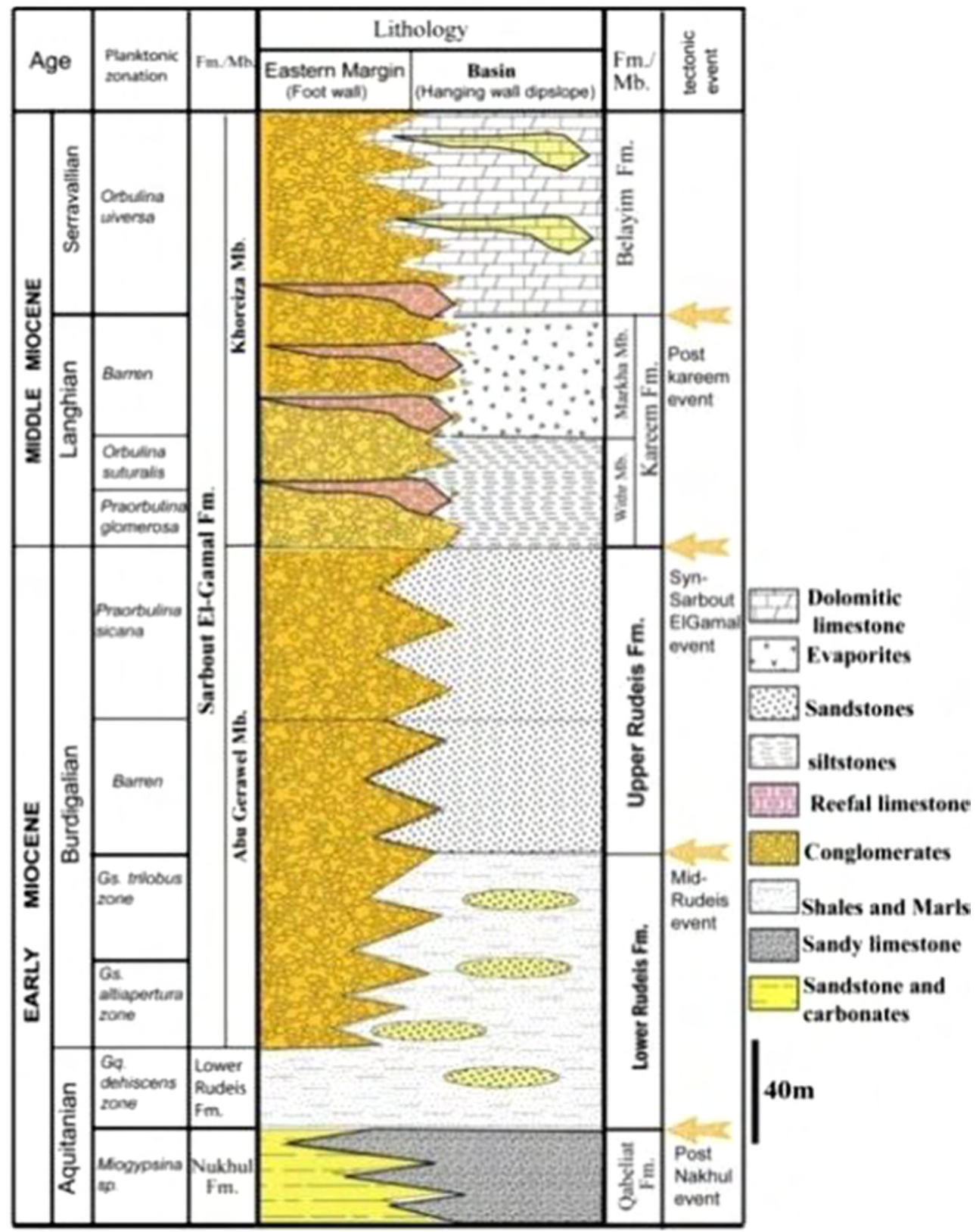

Figure 5. Stratigraphy of syn-rift Miocene rocks at W. Feiran basin (Mahran et al. 2001).

factors were analyzed to define which PC image can be used to highlight the target class based on the eigenvectors of selected bands. The first component contains the greatest variances that decreases through the second PC and the third, etc.

\subsection{Microwave data}

\subsubsection{SRTM}

The Shuttle Radar Topography Mission (SRTM) digital elevation model (DEM) of $90 \mathrm{~m}$ resolution was used for extracting streams, faults and shear zones, topographic cross-sections, contour maps, and 3D-perspective view. The shaded relief map was constructed from the SRTM DEMs by varying the azimuth and elevation of the simulated sun illumination using the ArcGIS software package. This procedure maximizes the visualization of a surface for better observation and graphical display, to allow extraction of lineaments by using shaded-relief process by changing the azimuth (Smith and Clark 2005).

The stream networks and the watershed were extracted using NASA Shuttle Radar Topography Mission (SRTM) data. This was performed by applying surface flow routing using the $8 \mathrm{D}$ flow 
direction algorithm (O'Callaghan and Mark 1984; Jenson and Domingue 1988). Moreover, the variations on topography was recognized along the traverse and longitudinal profiles that show the amplitude or change on the elevation along the traverse line that reflect tectonic element.

Quantitative topographic profiles would give an important indication of distribution of topography and the tectonic control. Therefore, several transverse profiles were performed to show the amplitude and change on the elevation along the profile line. Such a method would help to define the uplifts, tilting and to locate significant breaks in slope, measuring height and display low topography (Abdelkareem and El-Baz 2016).

The topographic profiles mostly across the river's flow direction, begins from upstream to downstream and such profiles were extracted for analyzing channel geometry. Longitudinal profile parallel to the wadi bed was generated to define the slope of the wadi using the extracted stream line. The oblique 3D perspective view was utilized to get valuable information about the terrain (e.g., Jordan et al. 2005). This allowed sharpening the topography and maximizing the extracted geometric and geologic information.

\subsection{Radarsat-1}

The Canadian Radarsat-1 was used to view the structures and the alluvial deposits in the present study. This active microwave sensor uses the Cband frequency (wavelength of $5.6 \mathrm{~cm}$ ), single horizontally polarized $(\mathrm{HH})$ with $12.5 \mathrm{~m}$ spatial resolution. The processes of georeferencing, transformation and enhancement were performed using ENVI 5 software package. The data were projected on a Universal Transverse Mercator (UTM) and WGS84 datum Zone $36 \mathrm{~N}$. The radar data was filtered by applying the enhanced Lee method (with a 3.3 window size) to obtain an enhanced image.

\section{Data integration/fusion/visualization}

\subsection{VNIR/radar fused image}

Data fusion using a principal component (PC) spectral sharpening algorithm was applied to highlight a low resolution multispectral data with a high resolution Radarsat-1 data using ENVI software package (Abdelkareem et al. 2012). This is to produce a hybrid image of spectral and geometric features. Such display in R, G, and B afford the best colour contrast in Landsat ETM+.

\subsection{Lineament extraction and analysis}

Visual, spatial, and statistical analyses and interpretation of the lineament features were carried out. Image analysis using a rose diagram and density map was applied using Rockworks 16 and ArcGIS software packages. The methodology of lineaments extractions include manual exporting using integration of optical and radar data. Moreover, we used the automatically-extracted streamnetworks in delineating the lineaments. This is because several streams look straight along a tectonic feature. The manual extraction delineates the lineaments which can be clearly identified within the image. Data from many LandsatETM+, SRTM, and Radarsat-1 sensors were utilized for that purpose.

\section{Results and discussion}

\subsection{Optical remote sensing}

Band combinations 5, 3, 1 in $\mathrm{R}, \mathrm{G}$, and $\mathrm{B}$ (figure 6a) have been proved to be effective for geological discrimination. This is based on the calculated optimum index factor (OIF) of the study area which gave the highest OIF values rather than others as shown in table 1. The dark colour represents iron-bearing minerals such as biotite, hornblende, and chlorite. Therefore, alkali feldspar granites and monzogranites display light colour tones, but gabbro, diorites, and granodiorites show relatively dark colour, respectively, in this combination. This is because diorites and granodiorites have hornblend and biotite more than those in alkali feldspar granites.

A false colour composite image using band ratios $5 / 7,5 / 4$ and $3 / 1$ in $\mathrm{R}, \mathrm{G}$ and $\mathrm{B}$, respectively, clearly highlighted the spectral characteristics of the rock units (figure $6 \mathrm{~b}$ ). The obtained image obviously discriminates between the sedimentary rocks (reddish to pinkish yellow) and the igneous and metamorphic rocks (bluish to greenish). The reddish-pinkish colour may be related to the predominance of $\mathrm{OH}$-bearing minerals (e.g., kaolinitesmectite, micas, amphiboles) that revealed by band ratio 5/7 (e.g., Gupta 2003). This is because the clay minerals show prominent absorption in band 7 (2.08-2.35) and high reflectance in band 5 (1.551.75). The granodiorites and monzogranites are 

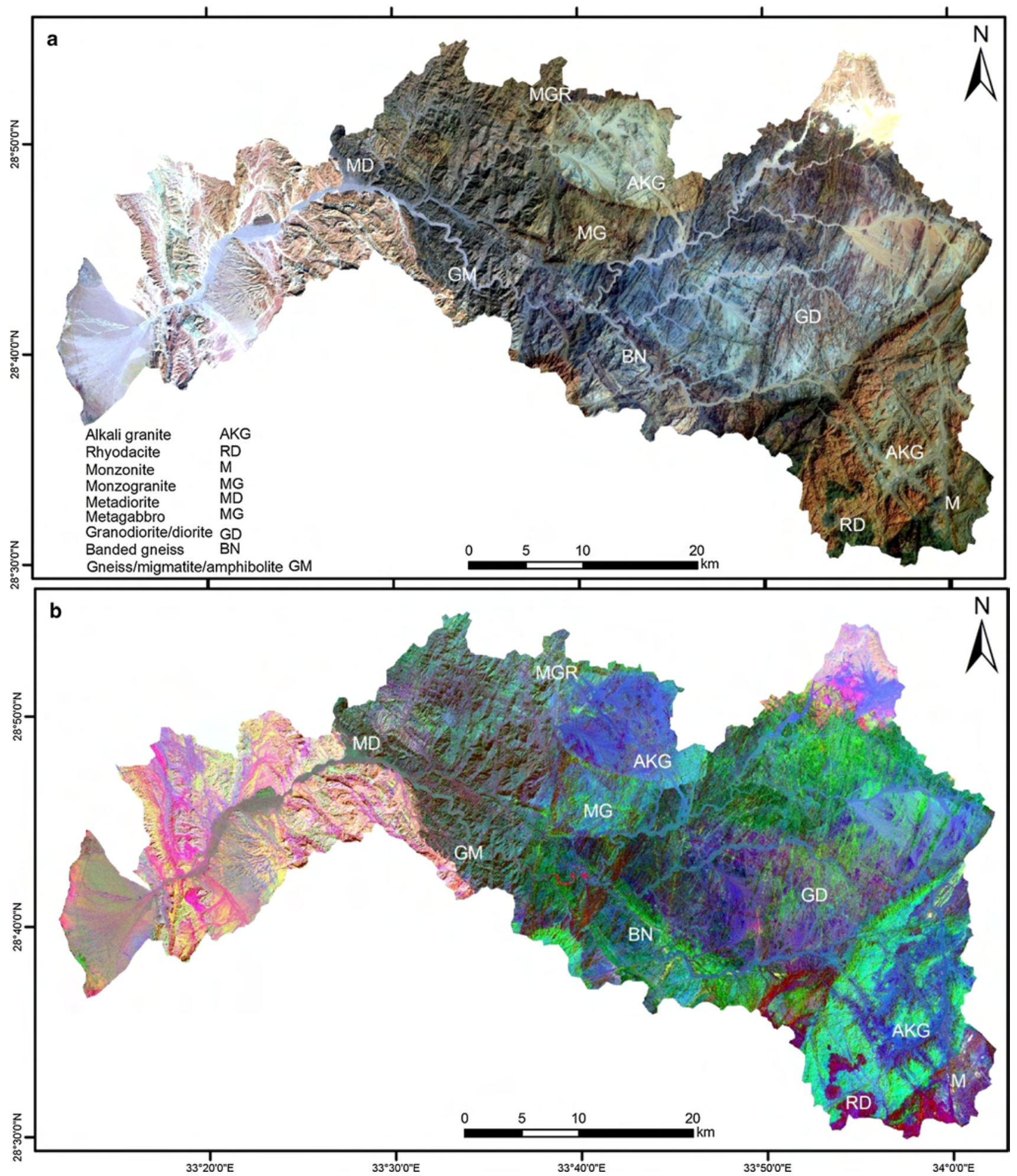

Figure 6. (a) Band combinations 5, 3, 1 in R, G, and B respectively, display the felsic rocks, sedimentary succession, and alkali-granites in light colours; however, rocks-bearing ferromagnesian minerals appear in dark; (b) Band ratios 5/7, 5/4 and $3 / 1$ in R, G, and B respectively, clearly display areas bearing clay minerals in reddish colours, rocks-bearing ferrous minerals in green and rocks-bearing ferric minerals in blue colours.

visible as bluish colour because band ratio $3 / 1$ is used for detecting iron oxides-bearing minerals; however, rocks bearing ferrous minerals appear in green, as in ratios band 5/4, the FeO-bearing alumina-silicates have absorption feature in band 4 (Chica-Olma 2002). 
Table 1. Calculated optimum index factor (OIF) of the study area.

\begin{tabular}{lcccccccccc}
\hline Band Combination & $1,2,3$ & $1,2,4$ & $1,2,5$ & $1,2,7$ & $1,3,4$ & $1,3,5$ & $1,3,7$ & $1,4,5$ & $1,4,7$ & $1,5,7$ \\
OIF & 22.95 & 21.31 & 26.02 & 22.77 & 25.07 & 29.84 & 26.57 & 27.90 & 24.68 & 29.08 \\
Band Combination & $2,3,4$ & $2,3,5$ & $2,3,7$ & $2,4,5$ & $2,4,7$ & $2,5,7$ & $3,4,5$ & $3,4,7$ & $3,5,7$ & $4,5,7$ \\
OIF & 26.38 & 30.99 & 27.84 & 29.01 & 25.93 & 30.12 & 32.13 & 29.08 & 33.14 & 30.93 \\
\hline
\end{tabular}

Table 2. Eigenvectors of covariance matrix of the six bands 1, 2, 3, 4, 5 and 7 of $W$. Feiran basin.

\begin{tabular}{lrrrrrrr}
\hline Eigenvector & Band 1 & Band 2 & Band 3 & Band 4 & Band 5 & Band 7 & Eigenvalue \\
\hline Mean & 0.152342 & 0.168075 & 0.210856 & 0.244810 & 0.287346 & 0.235375 & \\
Stdev & 0.040091 & 0.063901 & 0.090343 & 0.112445 & 0.136834 & 0.105187 & \\
PC1 & -0.159310 & -0.264320 & -0.381800 & -0.477640 & -0.580520 & -0.440260 & 96.938740 \\
PC2 & 0.354444 & 0.440376 & 0.382489 & 0.307059 & -0.401860 & -0.527600 & 2.066307 \\
PC3 & -0.093610 & -0.096050 & -0.175240 & 0.089268 & 0.655067 & -0.717090 & 0.566769 \\
PC4 & 0.576247 & 0.412031 & -0.162320 & -0.639130 & 0.245768 & 0.054200 & 0.321583 \\
PC5 & -0.379450 & -0.015170 & 0.757182 & -0.510990 & 0.108073 & -0.098360 & 0.067515 \\
PC6 & 0.603475 & -0.746310 & 0.278469 & -0.003600 & 0.017659 & -0.031180 & 0.039087 \\
\hline
\end{tabular}

In addition to the band ratios, the principal component analysis (PCA) is also applied. It is an image transformation technique that minimizes the dimensionality of data and separates noise component (Singh and Harrison 1985). In this transformation, the first component (PC1) consists of negative loading from all six bands (table 2). PC1 is represented by $96.93 \%$ of the total variance of the selected data and $\mathrm{PC} 2$ represents a difference between Visible/NIR (1-4) and SWIR bands (5, 7). Using $\mathrm{PC} 1, \mathrm{PC} 2$, and $\mathrm{PC} 3$ in $\mathrm{R}, \mathrm{G}$, and $\mathrm{B}$, respectively, the contact between basement and sedimentary rocks is clearly obvious as the sedimentary succession is visible in bluish purple colour (figure 7a). As potash feldspar displays a high reflectance in band 3 and a low reflectance in bands 1 and 2 (Liu et al. 2013), the PC5 displays bright pixels as a positive loading of band 3 and a negative loading of bands 1 and 2 . In the false colour composite of bands PC5, PC4, and PC3 in R, G, and $\mathrm{B}$, the potash feldspar granites are distinguished in pinkish red colour (figure $7 \mathrm{~b}$ ), whereas most of the granodiorites, diorites, migmatites, and gneisses are shown in green. The sedimentary rocks $(\mathrm{OH}-$ bearing minerals) appeared as bluish colours as PC3 displayed contrast between bands 5 (0.655067) and $7(-0.71709)$.
In order to detect if the basement rocks are fresh or subjected to hydrothermal activities, the principal component analysis on selected bands 1 , 4,5 and 7 was applied (table 3 ). In this transformation, bands 2 and 3 have been neglected to prevent mapping iron oxides, and it can be noted that bands 2 and 3 could be substituted for band 1 in this analysis (Mia and Fujimitsu 2012). This technique examines the eigenvector loading for bands 5 and 7 in PC3 and PC4. $\mathrm{PC} 2$ shows the contrast between the shortwave IR (SWIR) and the visible region. PC3 highlights the hydroxyl-bearing minerals as dark pixels that are invested to display a white tone (eigenvector loading for Band $7=0.639506$ and for Band $5=$ $-0.70737)$. There is a similarity between hydroxyls and carbonates in spectral behaviour (Tangestani and Moore 2000) that causes confusion in image interpretation.

In figure 8, the bright pixels represent the $\mathrm{OH}$-bearing minerals, therefore, the sedimentary rocks, most of the alluvial deposits and the Pleistocene and Pliocene deposits are shown in light tones. However, the magmatic rocks mostly displayed no alteration, except the light tone that occurred in the southeastern part of the study area including rhyodacites and monzonites. Most of the 


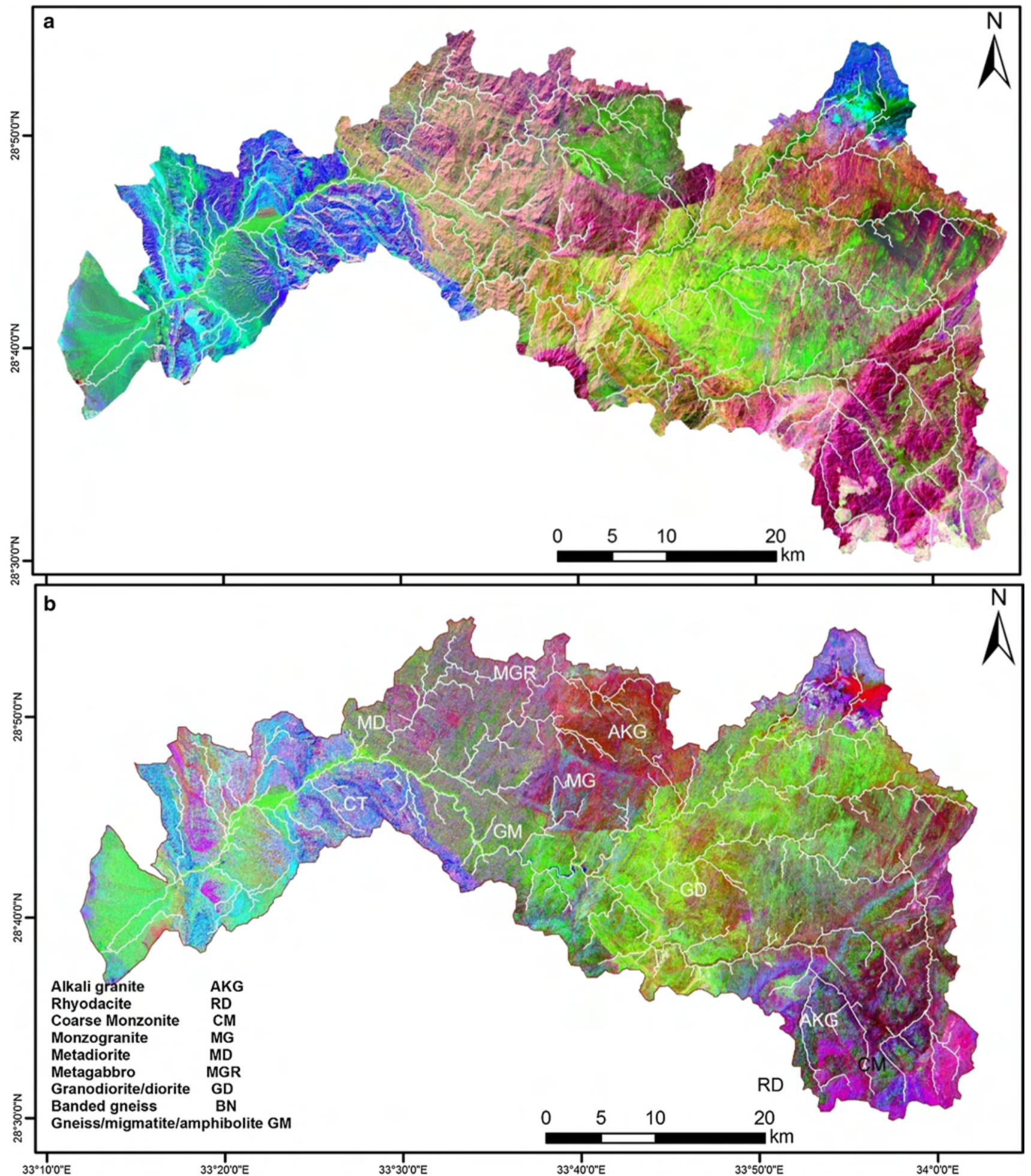

Figure 7. (a) PCs 1, 2, 3 in R, G, and B of the analyzed Landsat-7 ETM+ spectral bands (1, 2, 3, 4, 5, 7); (b) PC5, PC4, PC3 in R, G, and B of the selected Landsat-7 ETM+ spectral bands $(1,2,3,4,5,7)$.

study area comprises magmatic rocks almost rich in light coloured minerals and poor in coloured rock forming mafic minerals. Thus, during alteration processes of the hydrothermal solutions, the hydroxyl $(\mathrm{OH})$ group of the minerals are most likely produced more easily from alkali feldspar and plagioclase, which are predominated in the felsic volcanics indicating that the area is poor in $\mathrm{OH}-$ bearing minerals, and less or not affected by the hydrothermal alteration processes. 
Table 3. Eigenvectors of covariance matrix of the selected bands 1, 4, 5 and 7, for mapping the hydroxyl-bearing minerals alteration zones in W. Feiran basin.

\begin{tabular}{lrrrrr}
\hline Eigenvector & Band 1 & \multicolumn{1}{c}{ Band 4 } & \multicolumn{1}{c}{ Band 5 } & Band 7 & Eigenvalue \\
\hline Stdev & 0.040091 & 0.112445 & 0.136834 & 0.105187 & \\
PC1 & -0.176470 & -0.535760 & -0.657460 & -0.499570 & 97.431760 \\
PC2 & -0.474860 & -0.629590 & 0.198181 & 0.582113 & 1.587266 \\
PC3 & 0.227992 & 0.196657 & -0.707370 & 0.639506 & 0.658522 \\
PC4 & 0.831499 & -0.527170 & 0.167606 & 0.051067 & 0.322449 \\
\hline
\end{tabular}

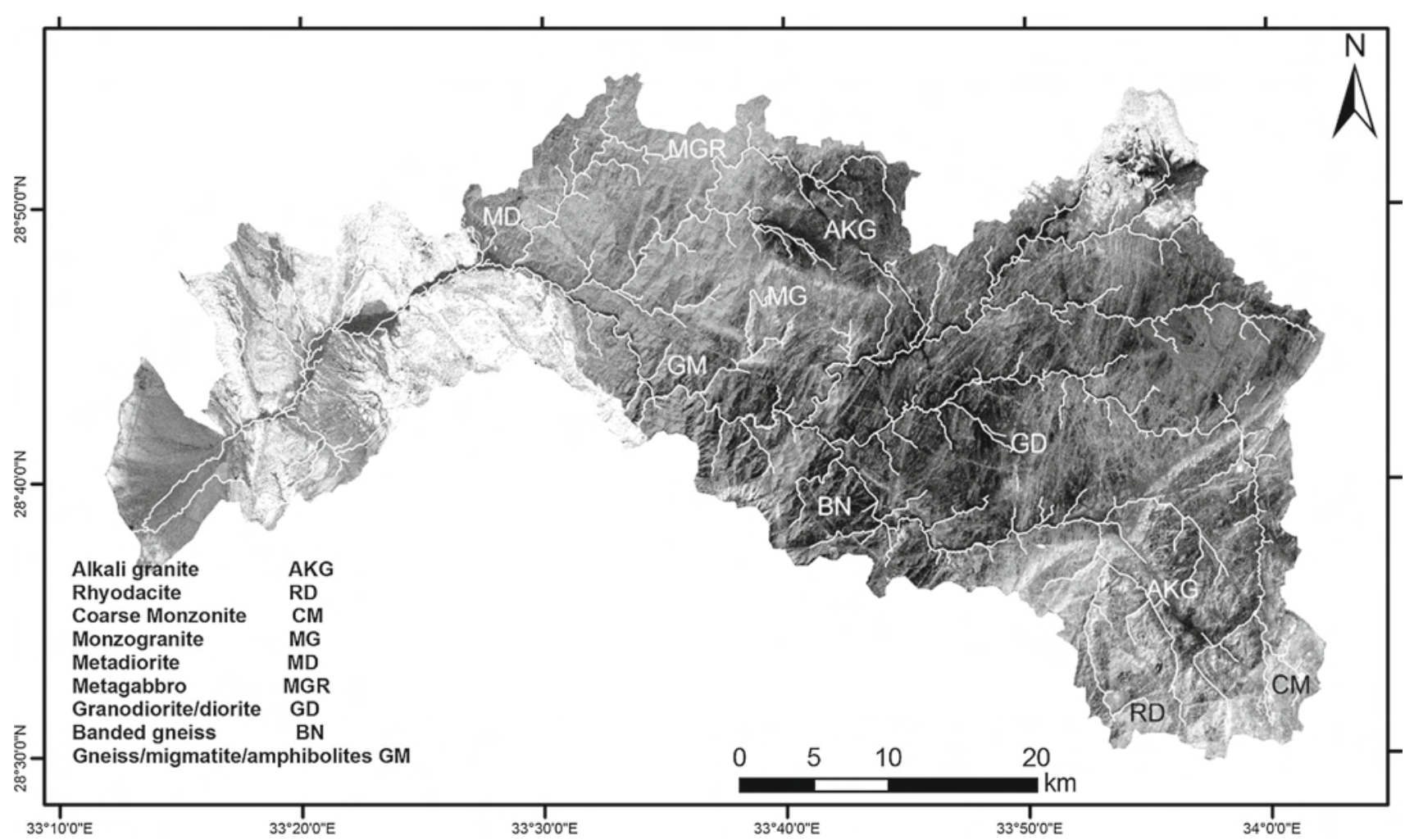

Figure 8. Negated H-image (PC3) displaying the OH-bearing minerals by applying the principal component analysis (PCA) of bands 1, 4, 5 and 7 . The negated images show the altered areas in bright pixels.

\subsection{Data fusion Radarsat-1/ETM+}

The Radarsat-1 data (figure 9a) and fused image of Radarsat-1/ETM+ of W. Feiran greatly enhanced the appearance of geology and geomorphology. In these images (figure 9), the sedimentary succession appeared as a low rugged terrain and is well discriminated from the basement rocks to the east. The dark tones are most likely due to the fine texture of the fluvial deposits along the valley bed. These deposits are loose sediments of sand and gravel. The middle and southern parts of the basin are very rugged terrains.

\subsection{SRTM DEM analysis}

Analysis and interpretations of SRTM DEM data revealed a meaningful information on the geomorphology and geometry of W. Feiran region that are difficult to identify by other remote sensing data. SRTM DEMs were used to visualize the variations in topography through several approaches such as longitudinal and traverse profiles, slope, contour maps, 3D views, and the geomorphic indices.

\subsubsection{D perspective view}

The eight-time $(8 \mathrm{x})$ vertical exaggeration topographic 3D perspective view (figure 10) showed that W. Feiran basin is surrounded by high relief of Pan-African highlands, particularly in northern and southern parts. The elevation reaches its peak in the eastern part of the upstream (e.g., St. Katherine $\sim 2618 \mathrm{~m}$ ) and declines in different directions, south, east, and north, bordering, 


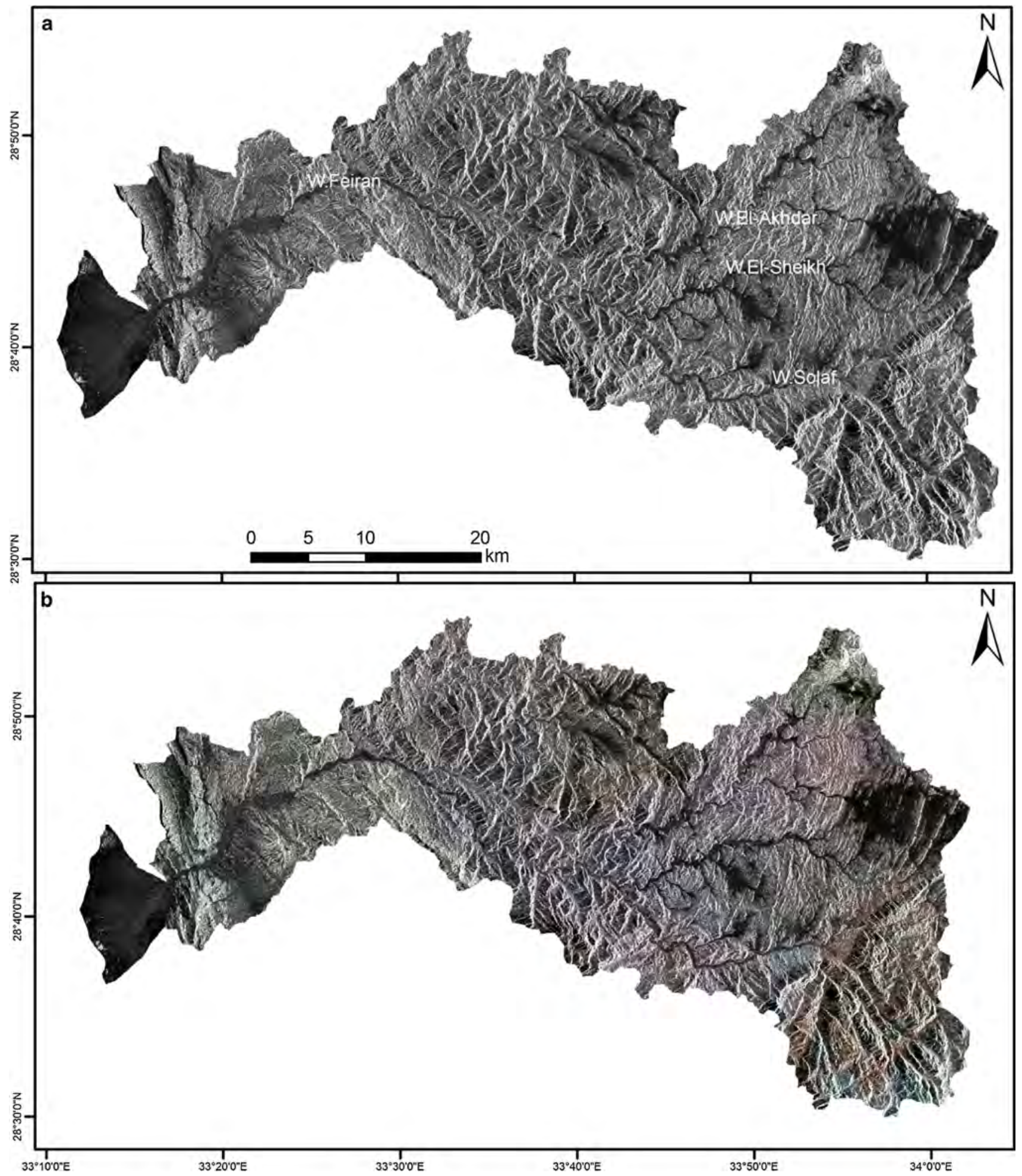

Figure 9. (a) Grey scale of Radarsat-1 data; the darkest tone refers to the fine deposits; however, the bright tone displays rough surface and the bed rocks. (b) Fused image of Radarsat-1/ETM+ displays the finer deposits in dark grey in the downstream areas and scattered along W. Feiran, and most of the study area is of rugged terrain.

e.g., W. El-Arish to the north. The higher areas $(\sim 2618 \mathrm{~m})$ in the southeastern part occupied by Alkali feldspar granites and rhyodacite that is represented by Gabal St. Katherine and Gabal Mousa in southern part of W. Feiran basin upstream.
The upstream of W. Feiran basin represents a midway between two elevated areas or hinge areas between two tilted landscapes such as W. El-Arish to north, and southern Sinai highlands to the south. This view clearly visualized the relationships 


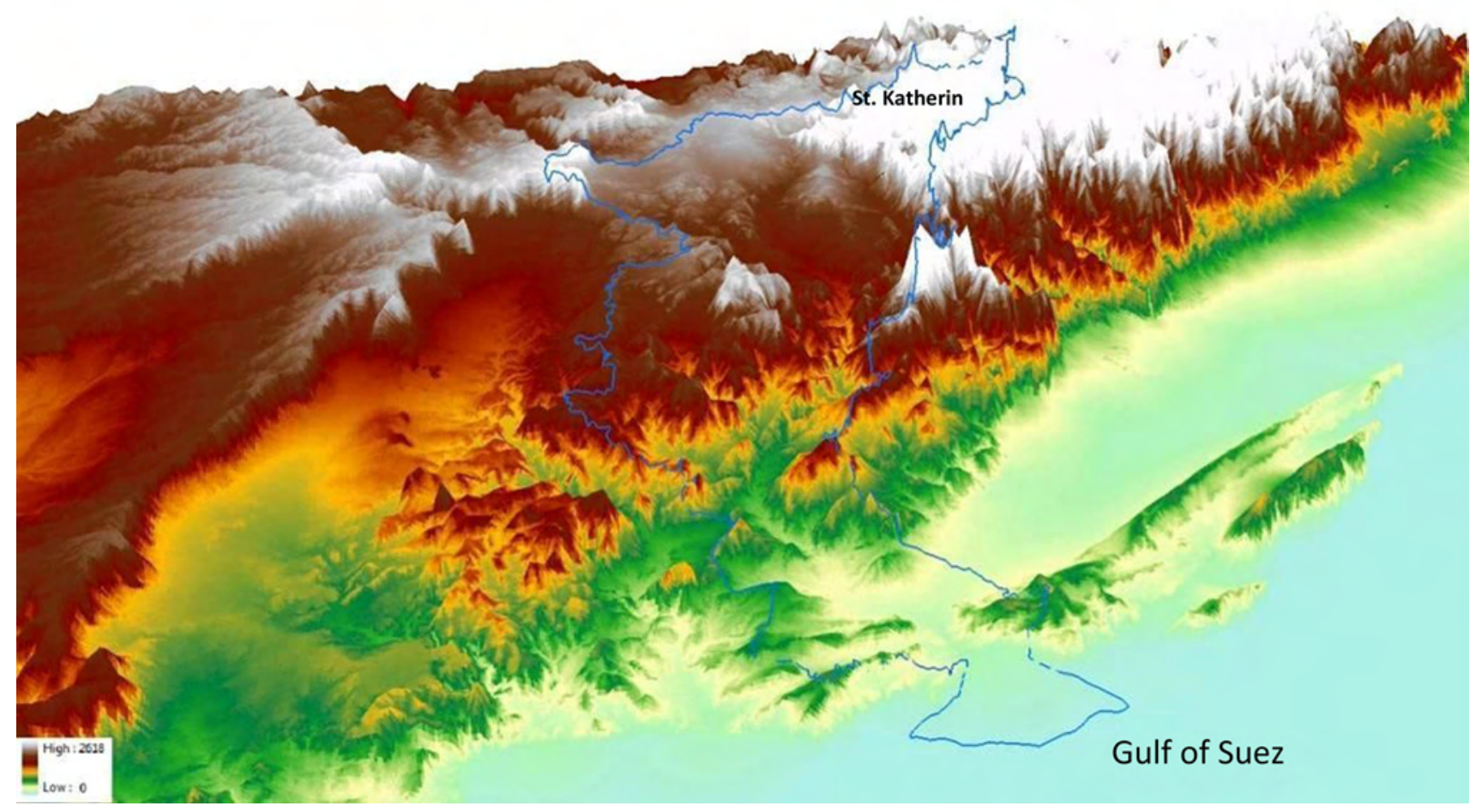

Figure 10. Oblique $3 \mathrm{D}$ view $(8 \times$ vertical exaggeration $)$ of $\mathrm{W}$. Feiran overlain by the watershed in a blue colour showing rugged terrain and the more elevated areas appear in white colour; however, the lowest elevations appear in cyan.

between the basin and the surrounding terrains as the area represents a peak of uplift and an upstream for several wadis such as W. El-Arish. In the middle section of W. Feiran, the elevated sides are represented by monzogranites to the north, and gneisses, migmatites, amphibolites, and mylonites to the south (refer to figure 1). This view confirms that the upstream sides are not symmetrically distributed.

\subsubsection{Elevation profiles}

The selected elevation profiles (figure 11) are chosen to characterize the changes in topography that reflect the structural control of the basin. Accordingly, two styles of topographic profiles are performed as follows: (1) transverse profiles cutting the main channel of W. Feiran, W. Solaf, W. El-Sheikh, and W. El-Akhdar. They are selected to show the variation in landscape elevations and shoulder contrast; (2) longitudinal profiles showing the tilting of valley floor for the mentioned wadis. The longitudinal profiles (P15/P16 to P23/P24) succeeded in revealing the maximum and minimum elevations and clearly determined the shape of the valley floor, i.e., concave, convex, straight or either. Such topographic profiles characterize the altitudinal contrasts, and allowed comparison of both shoulders of the wadi. The measured profiles P1-P2 to P13$\mathrm{P} 14$ showed non-systematic arrangement of elevations of mostly asymmetrical shoulders towards the downstream. The transverse profile P1-P2 (figure 12) showed asymmetric wadi shoulders, the southern shoulder is relatively higher $(>2000 \mathrm{~m}$ asl) where it is represented by sharp, almost vertical cliffs, often bounded the southern W. El-Sheikh along a structural element. The variability of the topographic surface along this profile revealed a rugged terrain. The topographic profile P3P4 at the southern part of W. Solaf is structurally controlled and represented by a cliff resting about $800 \mathrm{~m}$ above the valley floor $(\sim 1050 \mathrm{~m})$. Such profile, displayed a moderate roughness with more variable elevations northwards.

W. El-Sheikh floor is v-shaped, less than 1000 $\mathrm{m}$ (asl) in elevation and represented by asymmetric shoulders. Westwards, the transverse profile P5-P6 crossing W. Solaf, W. El-Sheikh, and W. El-Akhdar showed a stylolitic, very rugged terrain of v-shaped wadi floor along the entire landscape. The northern shoulder is relatively elevated $(>1200$ $\mathrm{m}$ asl) than the southern. The transverse profile 


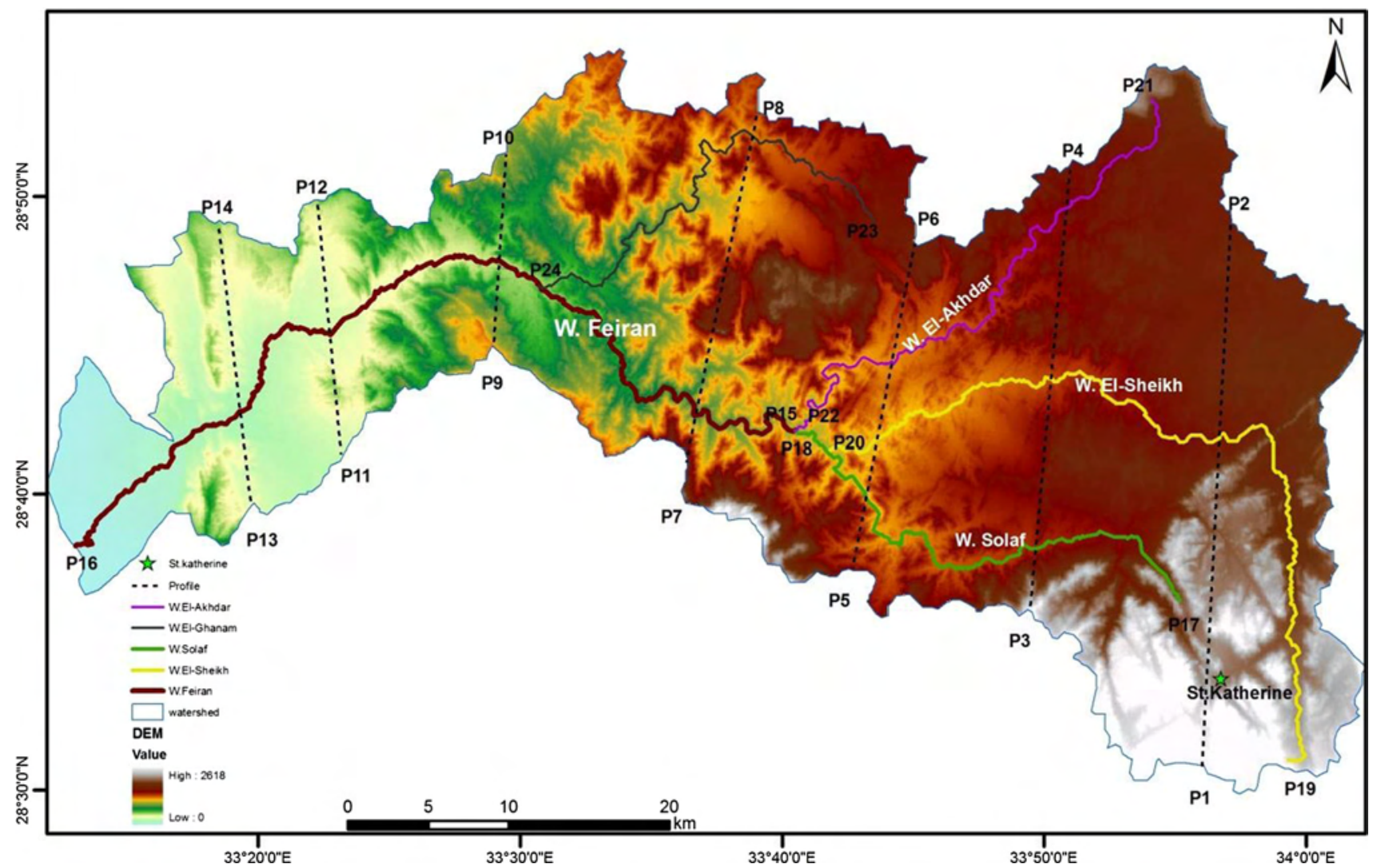

Figure 11. SRTM DEM covering W. Feiran basin overlain by longitudinal profiles along the main stream (P15-P16), W. Solaf (P17-P18), W. El-Sheikh (P19-P20), W. El-Akhdar (P21-P22) and transverse profiles (dashed black lines; P1-P2 to $\mathrm{P} 13-\mathrm{P} 14)$.

(P7-P8) crossing the main channel of W. Feiran displayed a v-shaped valley, moderately rugged terrain, asymmetric shoulders with the northern shoulder relatively elevated $(\sim 1300 \mathrm{~m})$ resulting in the sharp cliff of Gabal El-Banat facing W. Feiran, and northwards it showed an abrupt change in elevation.

Towards the downstream of W. Feiran, terraceslike near-symmetrical distributed on both the valley shoulders ( $\sim 300 \mathrm{~m}$ of the valley floor) (profile P9-P10). The downstream of W. Feiran which is generally occupied by sedimentary rocks, displayed a relatively U-shaped valley with a steep slope at the southern shoulder (profile P11-P12). Such a Ushaped valley is clearly obvious at the downstream section (profile P13-P14), and both shoulder elevations of the wadi are not systematically distributed by rugged terrains (frequent kinks, v-shaped valleys elevated between 250 and $400 \mathrm{~m}$ asl) and a wide saddle. The northern shoulder regularly elevated northwards reaching about $400 \mathrm{~m}$, however, the southern one is about $250 \mathrm{~m}$ (asl).

Analysis of the longitudinal profile along W. Feiran (P15-P16, figure 12) further displayed the main channel tilt of the southern part at about $70 \mathrm{~km}$ towards the mouth. The gradient of the wadi bed is moderate to high that reflects a high runoff during heavy rainstorms. No real convex, concave or either of them exist, however, a straight wadi floor displaying a regular tilting, and the transition between the landscapes is smooth. The longitudinal profile along W. Solaf displayed a concave shape. Through the first $5 \mathrm{~km}$ of the profile the tilting is moderate to high (1450-1100 m), and then gradually tilted westwards to join W. Feiran. This reflects the change of the lithology from Alkali granites to granodiorites/diorites, and gneiss rocks. The concave form is displayed in W. El-Akhdar and W. El-Sheikh (profile P19-P20; P21- P22, figure 13) as a result of lithological contacts.

\subsubsection{Slope}

The slope of W. Feiran ranges between $0^{\circ}$ and $60^{\circ}$ with a gentle slope at the downstream and northeastern parts of the basin, whereas the southeastern and middle parts displayed high slope 

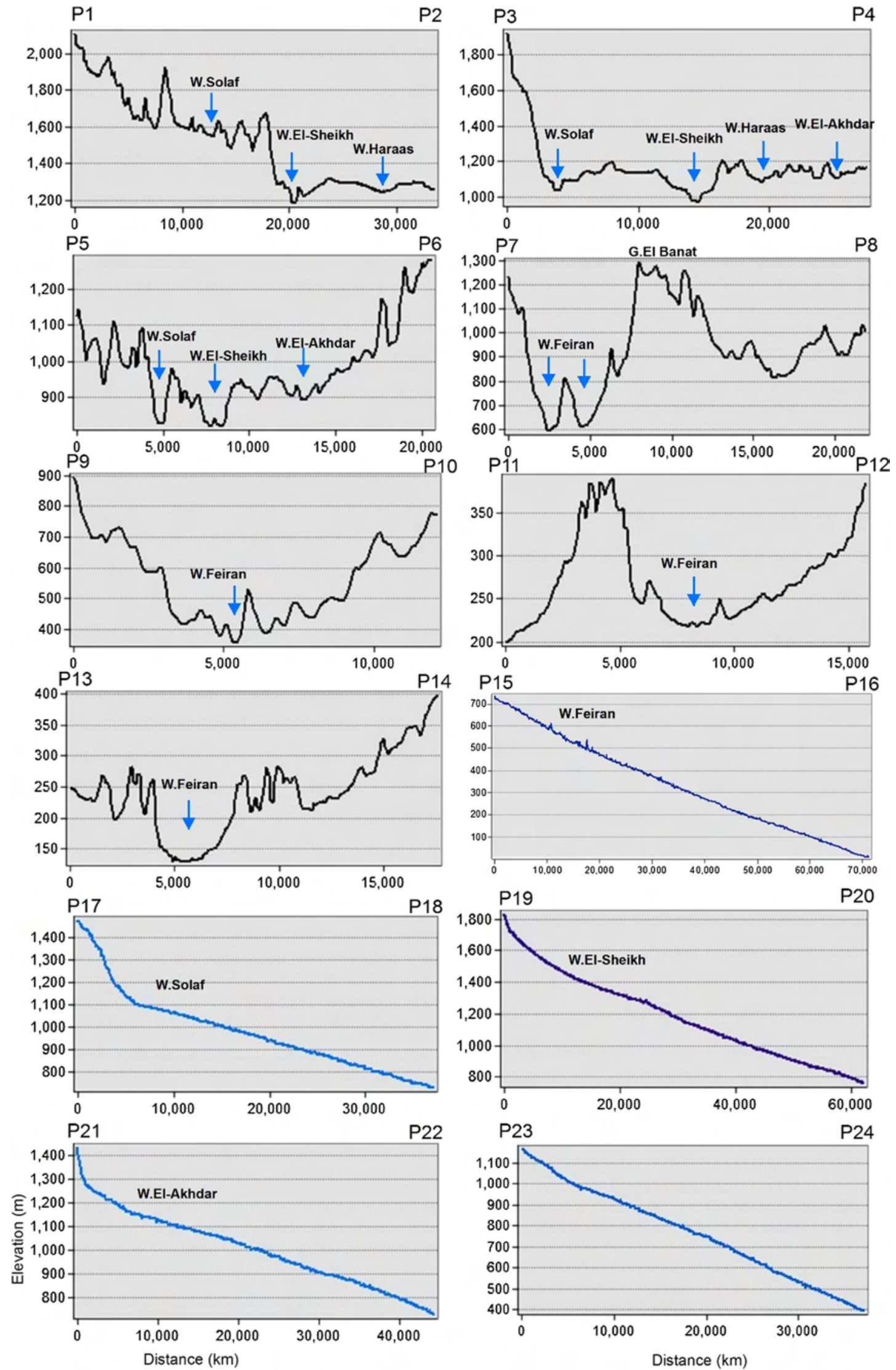

Figure 12. Transverse profiles of W. Feiran; (P1-P2 to P13-P14) crossing W. Feiran basin and its sub-basins and longitudinal profiles (P15-P16 to P23-P24) along the main stream and the sub-basins of W. Feiran, W. Solaf, W. El-Sheikh, and W. El-Akhdar. 

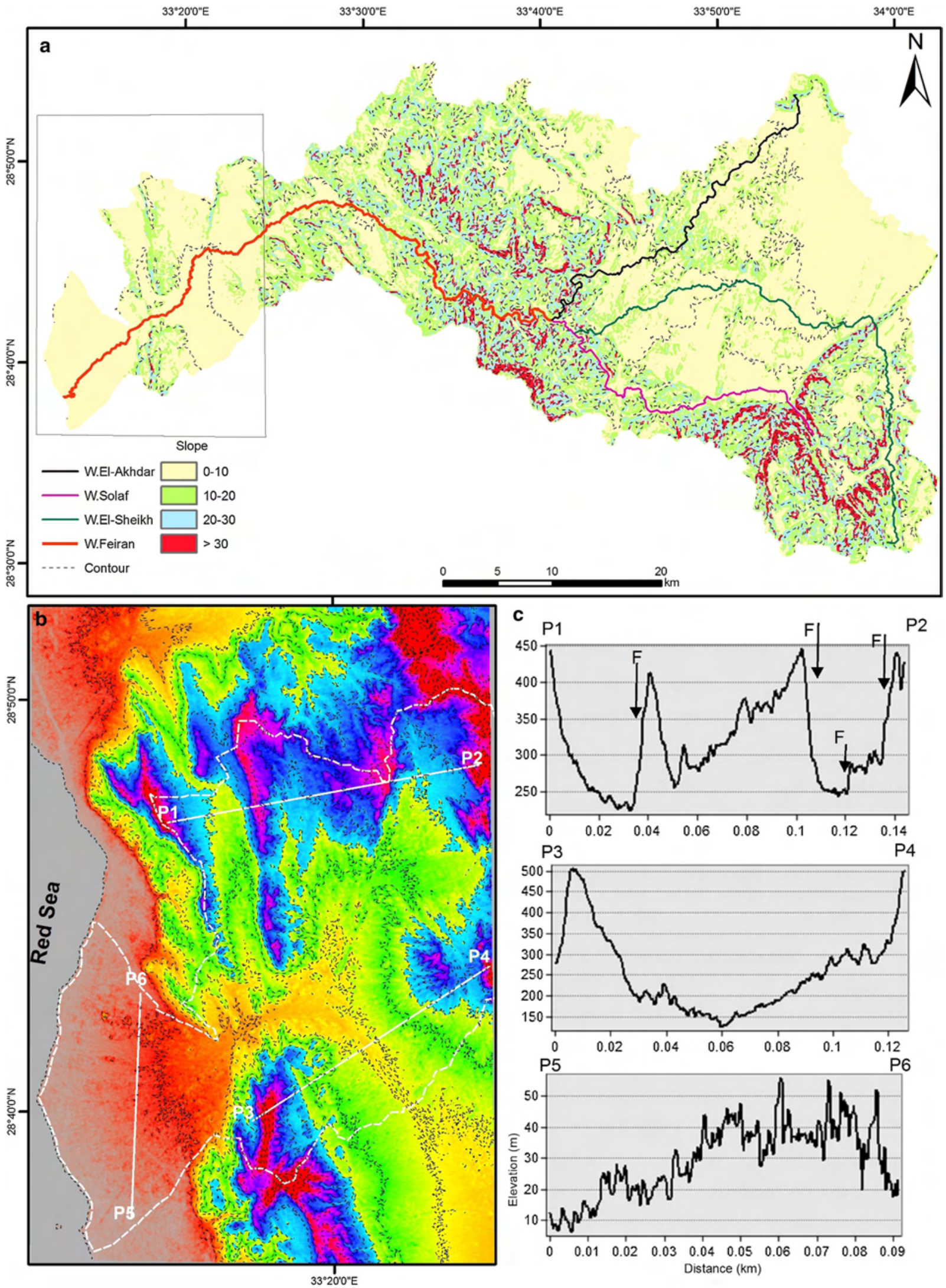

Figure 13. Downstream area of W. Feiran basin. (a) Slope classes revealing that slopes $0^{\circ}-20^{\circ}$ covering $>80 \%$ of the study area; (b) contour lines of W. Feiran displaying elongated shapes; and (c) transverse profile of the downstream area; P1-P2 displayed clear fault contacts that are highlighted by topographic contrasts; P3-P4 displayed a wide v-shape; and P5-P6 revealed a rugged terrain that is reflected by the accumulation of Plio-Pleistocene deposits. 
degrees (up to $\sim 60^{\circ}$ ). The slope of W. Feiran basin can be classified into four classes of $0^{\circ}-10^{\circ}$, $10^{\circ}-20^{\circ}, 20^{\circ}-30^{\circ}, 30^{\circ}-60^{\circ}$; occupying areas of about $57.57 \%, 25.32 \%, 12.71 \%$, and $4.37 \%$, respectively (figure 13a). The first class covers most of the study area, specially the downstream section and the northeastern part of the basin that comprises low relief granodiorites and diorites.

The distribution of contour lines revealed two patterns: (1) rugged terrain where the spacing of the contours is much closer, revealing a markedly steeper slope. This is obvious in the southeastern part of the study area, (alkali feldspar granite), and in the middle part of the basin; (2) varied terrain where the contours are highly curved, and the distance between contour lines are wide, even and considerable indicating a moderate and low slope. Such areas are coincidence with the areas that are occupied with granodiorite, diorite (upstream), and sedimentary rocks at the downstream. Subset of DEM of the downstream revealed that $\sim 20 \mathrm{~km}$ to the mouth is surrounded by elevated rock units up to $500 \mathrm{~m}$ (asl). The landforms that are obvious on contour lines revealed spur and ridges which are common along the wadi as the contour lines display elongated of very close space. The mouth of this basin is wide delta-like shape (figure 13b), undulated elevation ranges from 0 to $50 \mathrm{~m}$ (asl). The straight line contours, revealed a structural element such as at the right side of the downstream (looking downstream) that revealed a fault line (figure 13b, c).

\subsubsection{Geomorphic indices}

The quantitative measurements and geomorphic indices are extracted using the digital elevation model (SRTM). The calculated indices include the drainage basin shape, the hypsometric integral, the asymmetry factor, and the valley floor height-towidth ratio as follows:

\section{- Drainage basin shape (Bs)}

Drainage basin shape $(B s)$ was estimated from the following equation (e.g., Canon 1976; RamirezHerrera 1998):

$$
B_{s}=\frac{B_{l}}{B_{w}}
$$

where $B_{l}$ represents the basin length that is calculated from its outline to the most distant point in the drainage divide, and $B_{w}$ is the basin width. The calculated value of $B_{s}$ of $\mathrm{W}$. Feiran is 1.83 which revealed an elongated basin, generally connected with a relatively tectonic activity.

\section{- Hypsometric integral $\left(H_{i}\right)$}

The hypsometric integral $\left(H_{i}\right)$ describes the distribution of elevation in a given area of the landscape particularly a drainage basin (Strahler 1952). This index was calculated using the following equation (Pike and Wilson 1971; Mayer 1990; Keller and Pinter 2002):

$$
H_{i}=\frac{\text { Elev }_{\text {mean }}-\text { Elev }_{\text {min }}}{\text { Elev }_{\max }-\text { Elev }_{\text {min }}},
$$

where Elev $_{\text {mean }}$ is the mean elevation, Elev min and Elev $_{\max }$ are the minimum and maximum elevations within the watershed.

In general, the high values of the hypsometric integral indicate deep incision and rugged relief, however, intermediate and low values of the integral are associated with more evenly dissected drainage basins. The calculated $H_{i}$ of the studied basins (table 4) ranges from 0.439275 to 0.497248 . According to Khavari et al. (2010), these values (0.4-0.5) are considered as intermediate (concaveconvex or straight), however, no values of $H_{i}$ are less than 0.4 (concave shape).

\section{- Asymmetry factor}

Asymmetry factor is used to determine the tectonic influence (tectonic tilt in the area). This factor (Hare and Gardner 1985) is computed as follows:

$$
A_{f}=\frac{A_{r}}{A_{t}} * 100
$$

where $A_{r}$ is the area on the right side of the basin, (when looking downstream), $A_{t}$ is the total area.

Assuming that W. El-Sheikh in the midline of the entire W. Feiran basin (figure 14a), the $A_{r}=$ $1081 \mathrm{~km}^{2}$; and $A_{t}$ (total area) $=\sim 1785.4 \mathrm{~km}^{2}$. Therefore, the AF of the study area is about 60.55 . However, in case of $\mathrm{W}$. Solaf is the midline, the $A_{r}=1370.51 \mathrm{~km}^{2}$, and so the $A_{f}=76.76$. This factor either above or below 50 (neutral value) indicates a tectonic tilt.

In case of W. El-Sheikh, the southern part of the basin covers $\sim 41.47 \%$ of the W. Feiran basin; however, in case of W. Solaf (figure 14b), the southern part covers $\sim 25.80 \%$ of the W. Feiran basin. In either case, the northern part represents a large 
Table 4. The hypsometric integral $\left(H_{i}\right)$ values of $W$. Feiran basin.

\begin{tabular}{lcccc}
\hline Basin & Elev $_{\max }$ & Elev $_{\min }$ & Elev $_{\text {mean }}$ & $H_{i}$ \\
\hline W. Solaf & 2618 & 761 & 1598.350 & 0.450915 \\
W. El-Sheikh & 2609 & 762 & 1631.873 & 0.470965 \\
W. El-Akhdar & 1620 & 732 & 1173.556 & 0.497248 \\
W. Feiran & 2618 & 0 & 1270.113 & 0.485146 \\
\hline
\end{tabular}

area of the entire basin, reflecting a tilt and a massive tilt towards the south. The most significant asymmetry is visible in the middle part of the basin, where the metamorphosed rocks are located. The southern section is characterized by short wadis rather than the northern shoulder, revealing the effects of the tilting or the slope gradient.

\section{- Valley floor height-to-width ratio}

The $v$-ratio is related to the shape of the valley and is calculated by the following equation (Keller and Pinter 1999):

$$
v f=2 v f w /[(E l d-E s c)+(E r d-E s c)],
$$

where $v f$ is the valley-floor width-to-height ratio, $v f w$ is the valley floor width, Eld is height of the left shoulder and Erd is the height of the right shoulder, Esc is the absolute height of the valley floor.

The computed $v$-ratio of 31 sectors (figure 14c) ranged from 0.01 to 13.3 . About $67 \%$ of the calculated segments are below 1, which is connected to incision of the area that are subjected to tectonic activity (Silva et al. 2000). However, Bull (2007) considered that vf-ratio below 0.5 is related to active tectonics. This is because areas undergoing tectonic uplift are mostly characterized by v-shaped valley profiles with narrow incised streams, therefore the $v f$ ratio is low. Most of the profiles seem to indicate that recently the valley has reached equilibrium between uplift and denudation, with a v-shaped profile. Moreover, lithology played an important role where the presence of hard rocks (e.g., Alkali feldspar-granites, granodiorite, diorite, rhyodacite, and monzogranite) in upstreams dominated the v-shaped valleys. However, high ratios $(v f>1)$ are consistent with valleys with a flat floor (U-shape), where the erosion dominated over tectonics, indicating that denudation rates predominated over uplift rates and therefore the region would be under tectonic stability. Moreover, the presence of the soft sedimentary rocks such as Upper Cretaceous/Lower Tertiary sequence (shale, sandstone, limestone) reflect higher $v f$-ratio.

Low $v$-ratio at W. Solaf compared to that of W. El-Sheikh and W. El-Akhdar is related to the surrounding tributaries that are more resistant elevated landscape of the alkali-granites, rhyodacite rather than the granodiorites and diorites that occupied most of W. El-Sheikh and W. El-Akhdar which are of low relief, slope and denudated rocks. At the downstream of W. El-Sheikh, the vf-ratio increased resulting from the change in Lithology. In general, the value of $v$-ratio is low for most of the study area, with the exception of the downstream area that is dominated by weak rocks of major lateral erosion.

\subsubsection{Lineament extraction and analysis}

Six hillshade relief images (figure 15) are used to highlight the structural and geomorphic features that represented linear features in the present study. This is based on changing the light sources coming from six different directions with or without change of the $Z$ value. The first shaded relief image obtained by setting the sun azimuth $315^{\circ}$, and a solar elevation of $30^{\circ}$, and $Z=1$ (default values). This image produces a good contrast in areas of relatively high elevation such as southeastern and middle parts of the study area. To maximize the extracted information, the $Z$ value was set to be $10 \mathrm{x}$. The other illumination directions $250^{\circ}, 120^{\circ}, 45^{\circ}, 90^{\circ}$, and $315^{\circ}$ used the sun elevation 45 and $Z=10 \mathrm{x}$. Therefore, the results displayed enhancement in edges and highlighted features such as landforms and lineaments. For example, the sedimentary ridge in the downstream is clearly obvious in illumination direction $45^{\circ}, 90^{\circ}$, and $120^{\circ}$ against others. Combined directions of $250^{\circ}, 120^{\circ}, 45^{\circ}, 90^{\circ}$, and $315^{\circ}$ in multi-illumination directions are also investigated. 

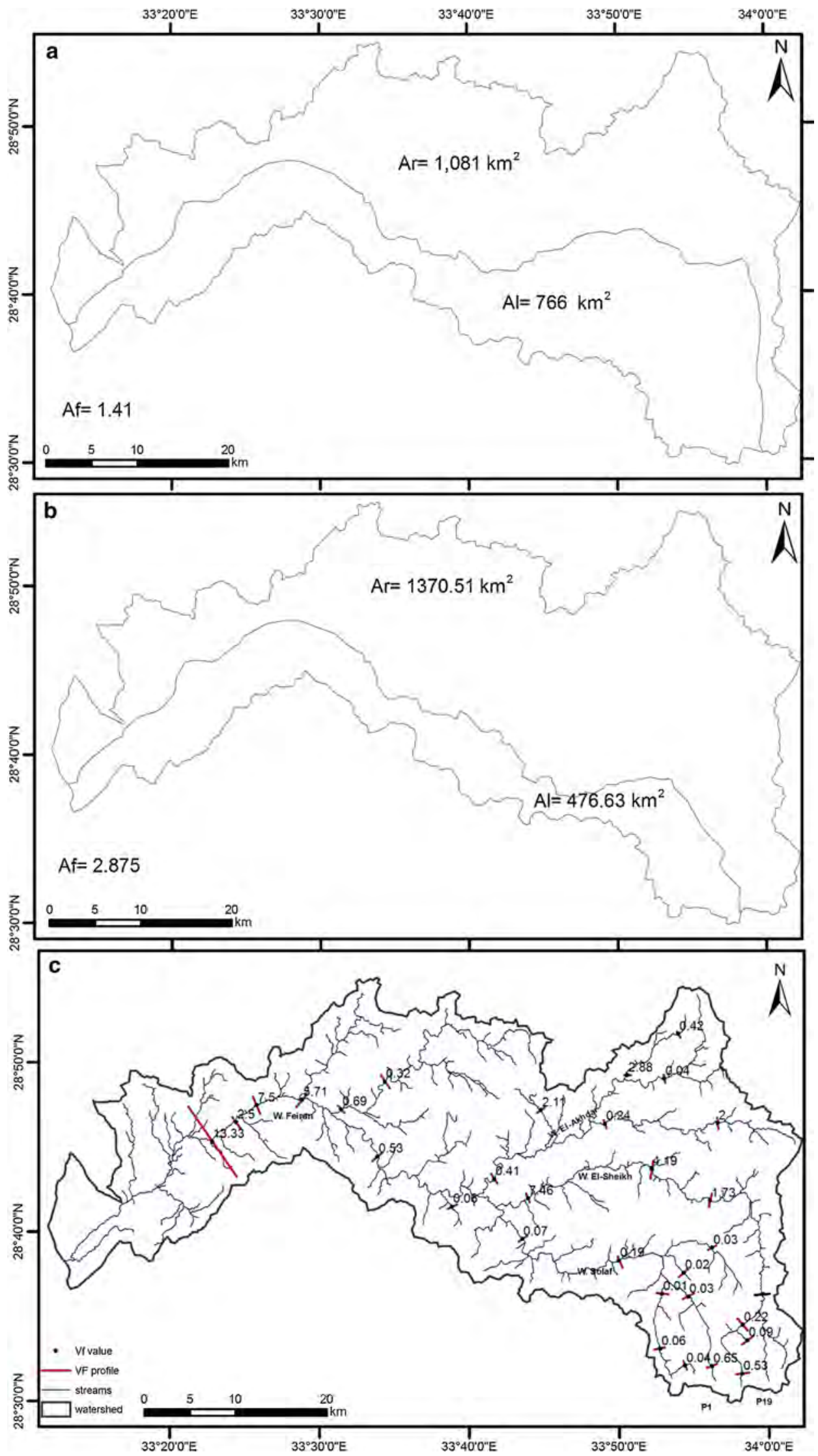

Figure 14. Asymmetry factor of W. Feiran basin. (a) Assuming that W. El-Sheikh is the midline of the basin; (b) based on W. Solaf is the midline of the basin; and (c) distribution of valley floor width to height ratio of W. Feiran. 

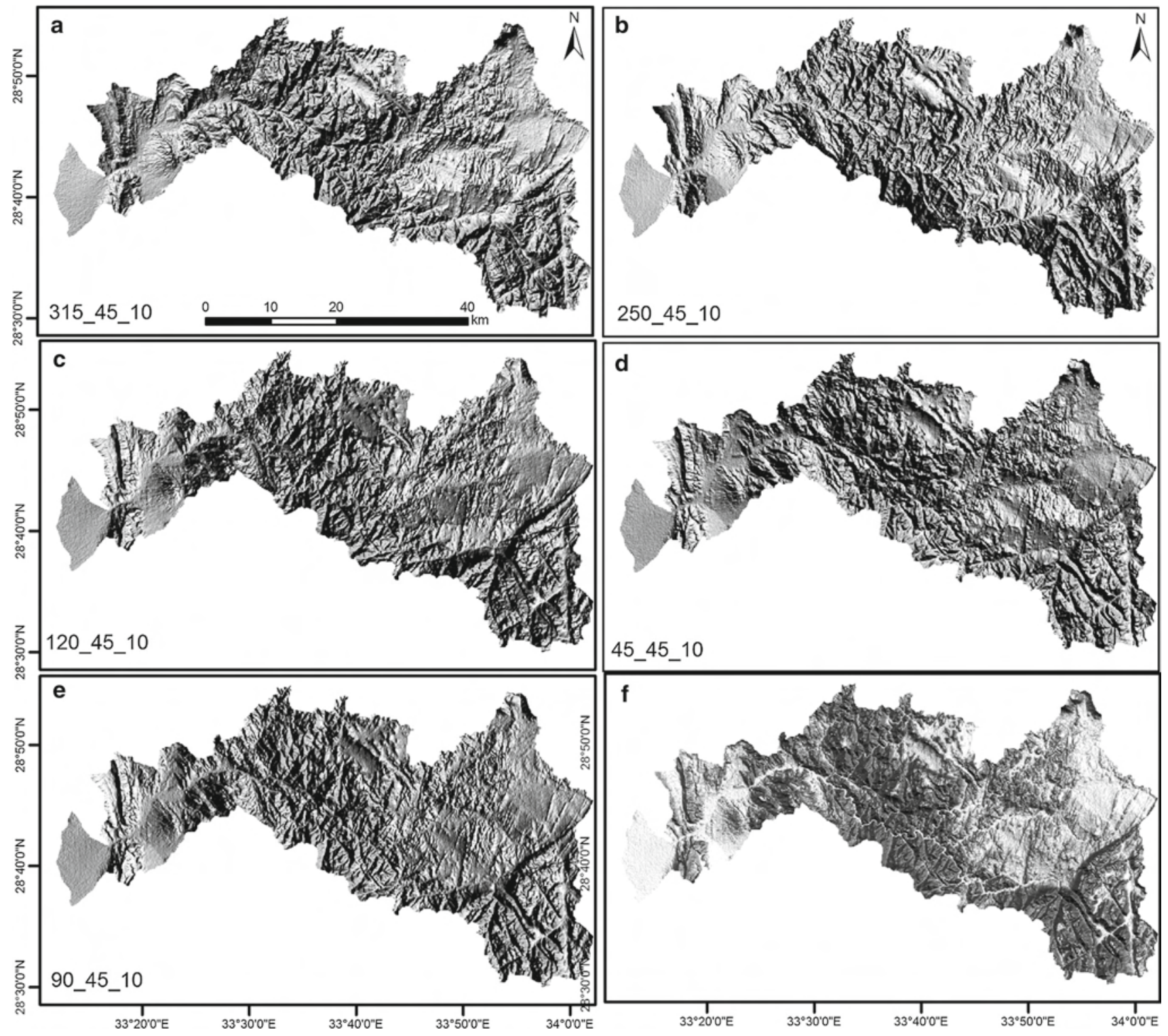

Figure 15. Shaded relief derived from SRTM DEM with different illumination directions (sun azimuth, altitude angle, and Z maximization). (a) Illumination directions $315^{\circ}, 45^{\circ}, 10$; (b) illumination directions $250^{\circ}, 45^{\circ}$, 10; (c) illumination directions $120^{\circ}, 45^{\circ}, 10$; (d) illumination directions $45^{\circ}, 45^{\circ}, 10 ;(\mathbf{e})$ illumination directions $90^{\circ}, 45^{\circ}, 10$ and (f) combined multi-azimuth directions, $250^{\circ}, 120^{\circ}, 45^{\circ}, 90^{\circ}$, and $315^{\circ}$.

The results showed that the prominent ridges, lineaments, and drainages are clearly enhanced by increasing the contrasts (figure 15). Variations of sun azimuth, solar elevation and height exaggeration in DEM data and shaded relief image provided much information by enhancing some features that help to increase the interpretation accuracy.

The results of the lineament density map (figure 16a, b) and distribution of lineaments revealed that the older crystalline rocks (e.g., gneiss, migmatite, diorite and granodiorite) in the investigated area are highly fractured, whereas alkali granites, and volcanic rocks displayed a lesser density. The lineament density map also revealed a discontinuous distribution on the area due to major tectonics particularly shearing. Plotting lineaments on the rose diagram (figure $16 \mathrm{c}, \mathrm{d}$ ) revealed that the study areas is dominated by the trends N20 $45 \mathrm{E}, \mathrm{N} 30-45 \mathrm{~W}, \mathrm{~N}-\mathrm{S}$ and $\mathrm{E}-\mathrm{W}$ respectively, according to their abundance. The $\mathrm{N}-\mathrm{E}$ lineaments are longer and more abundant than the $\mathrm{N}-\mathrm{W}$ trends. 

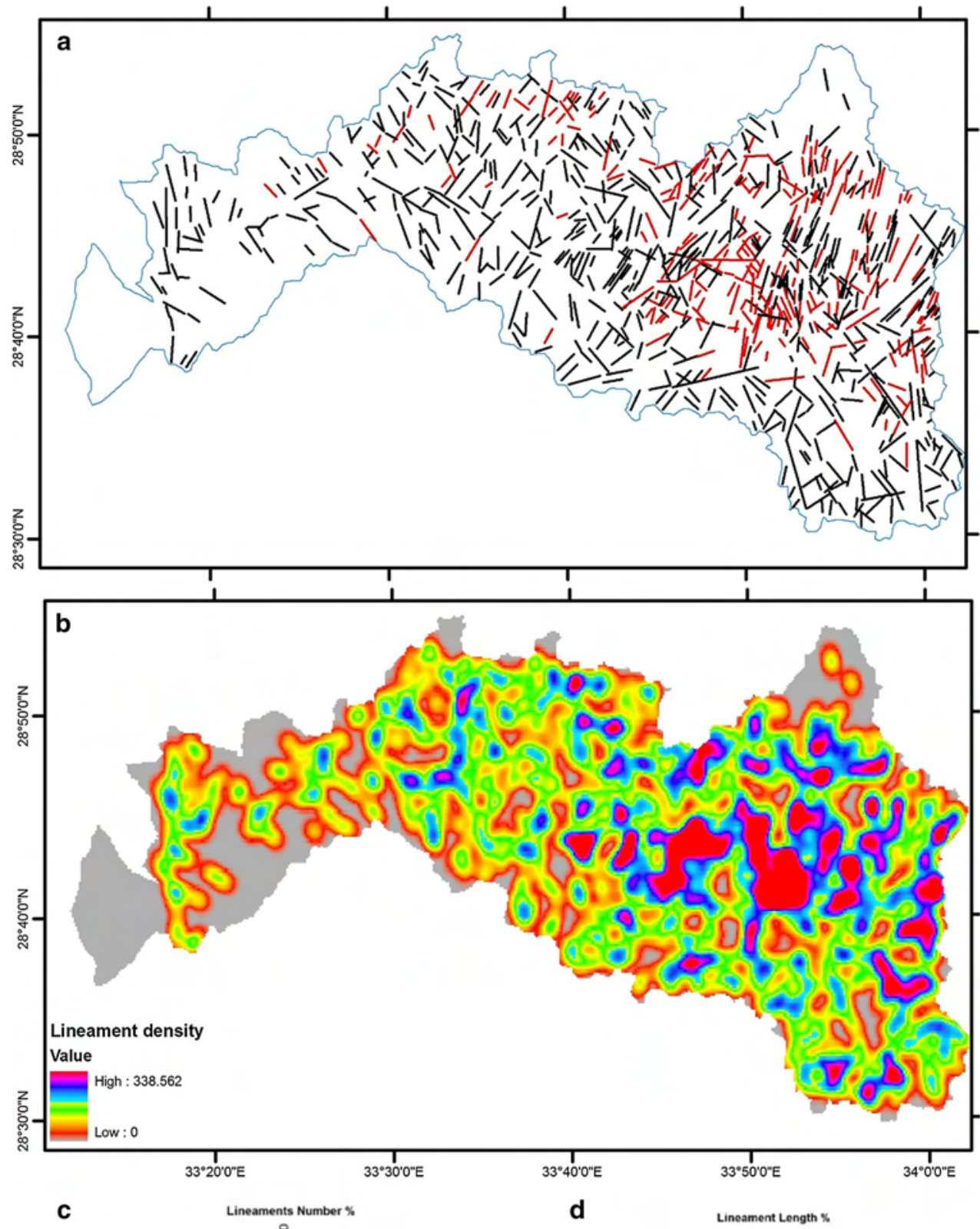

C

ㅇ

○.

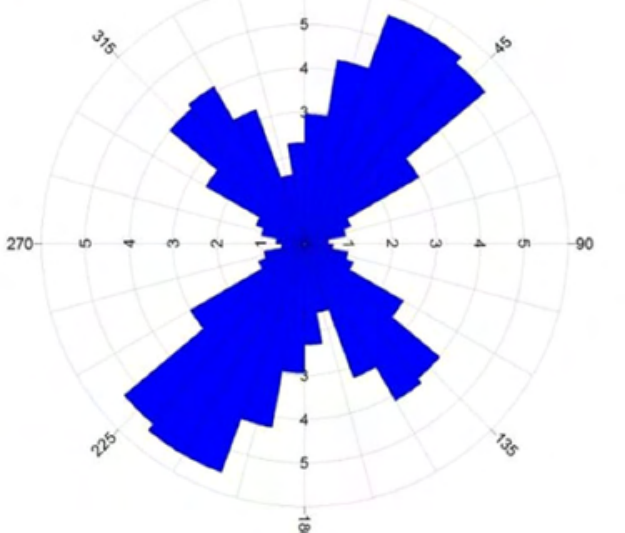

3

$x^{6}$

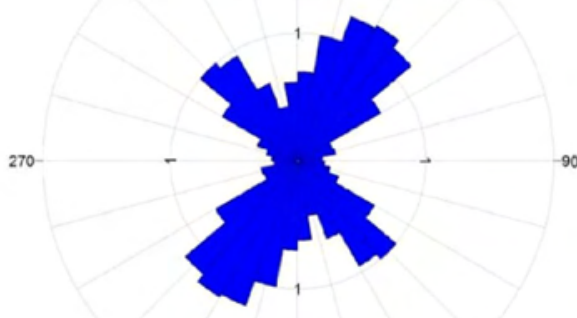

$\vartheta^{5}$

多

Figure 16. Lineaments extraction of W. Feiran basin. (a) Lineaments in black colour are extracted from shaded relief map, lineaments in red colour are extracted from Landsat image; (b) lineament density map of W. Feiran; the high density areas appear in red, however, the low density areas appear in grey colour; (c) Rose diagram represents the lineament frequency of NE-SW and NW-SE; and (d) lineament lengths showing that the lengths of lineaments are abundant in the NE direction. 


\section{Conclusions}

Wadi Feiran is located in southern Sinai Peninsula of Egypt. It covers about $1785 \mathrm{~km}^{2}$. It is made up of Precambrian basement rocks that are overlain by Phanerozoic rocks which are represented by Cretaceous/Tertiary succession; Miocene, Pliocene and Pleistocene deposits. Landsat-7 ETM+, SRTM DEM, Radarsat-1 data were analyzed to reveal the lithologic and geomorphic characteristics of the studied terrain. Several approaches such as band ratios and principal component analysis (PCA) were applied to Landsat-7 ETM+ data in order to discriminate and visualize the different rock units, and reveal any hydrothermal alteration in the study area. The results revealed that the basement rocks have not been modified by the hydrothermal alteration but cut by swarms of mafic and felsic dykes that trend in NW-SE and NE-SW. These interpretations are validated by the field investigations. In addition to Landsat data, radar images include Radarsat-1 and SRTM DEM that successfully allowed visualizing of the geomorphic characteristics and surface roughness. Analysis of SRTM DEM provide significant information on the geomorphic indices including drainage basin shape $(B s)$, asymmetry factor, hypsometrical integral, valley floor height-to-width ratio along with traverse profiles which is difficult to be visualized by other data. The results of the analyzed indices derived from remote sensing data demonstrated that W. Feiran basin is an elongated asymmetric shape that is controlled by NW-SE trend related to Red Sea. Its geomorphic and geometric shape implies that the basin was definitely generated by a tectonic uplift. Although, the used data was in low to medium resolution, results revealed that integration of optical and radar remote sensing techniques are significant in deciphering geomorphic, structural, rock types and morphometric features in several environments, and the used techniques are applicable in several areas in order to generate new and reliable geological information.

\section{Acknowledgements}

This project was financially supported by the Science and Technology Development Fund (STDF), Egypt, Grant No. 5790.

\section{References}

Abdelkareem M, El-Baz F, Askalany M, Akawy A and Ghoneim E 2012 Groundwater prospect map of Egypt's Qena Valley using data fusion; Int. J. Images Data Fusion 3(2) 169-189.

Abdelkareem M and El-Baz F 2015 Evidence of drainage reversal in the NE Sahara revealed by space-borne remote sensing data; J. Afr. Earth Sci. 110 245-257.

Abdelkareem M and El-Baz F 2016 Mode of formation of the Nile Gorge in northern Egypt by DEM-SRTM data and GIS analysis; Geol. J. 51(5) 760-778.

Abou El-Magd A A 2003 Quantitative hydrogeological studies on Wadi Feiran basin, South Sinai, with emphasis on the prevailing environmental conditions. M.Sc. Thesis, Geology Department, Faculty of Science, Suez Canal University, Egypt, 252p.

Abu-Alam T S 2010 Metamorphic and Structural Evolution of the Wadi Feiran Complex, Southwest Sinai; Doctor of Science, Doctoral School of Earth Sciences, Karl-Franzens University of Graz, 133p.

Alrikabi A, Elmewafey M, Beshr A and Elnaggar A A 2015 Using GIS based morphometry estimation of flood hazard impacts on desert roads in South Sinai, Egypt; Int. J. Sci. Eng. Res. 6(7) 1593-1599.

Amarsaikhan D, Blotevogel H H, Van Genderen J L, Ganzorig M, Gantuya R and Nergui B 2010 Fusing highresolution SAR and optical imagery for improved urban land cover study and classification; Int. J. Image Data Fusion 1(1) 83-97.

Amarsaikhan D, Gantuya R and Battsengel V 2009 Applications of remote sensing and geographic information systems for urban land-cover changes studies; Geocarto Int. 24(4) 257-271.

Arnos M O 2016 Groundwater potentiality mapping of hardrock terrain in arid regions using geospatial modelling: Example from Wadi Feiran basin, South Sinai, Egypt; Hydrogeol. J. 24(6) 1375-1392.

Aydal D, Arda1 E and Dumanlilar O 2007 Applications of Crosta technique for alteration mapping of granitoidic rocks using ETM+ data: Case study from eastern Tauride belt (SE Turkey); Int. J. Remote Sens. 28(17) 3895-3913.

Be'eri-Shlevin Y, Katzir Y and Valley J 2009 Crustal evolution and recycling in a juvenile continent: Oxygen isotope ratio of zircon in the northern Arabian Nubian Shield; Lithos 107(3-4) 169-184.

Bentor Y K 1985 The crustal evolution of the Arabo-Nubian Massive with special reference to the Sinai Peninsula; Precamb. Res. 28 1-74.

Bielski M 1982 Stages of the evolution of the ArabianNubian massif in Sinai; Ph.D. Thesis, Hebrew University, Jerusalem, 155p.

Bull W B 2007 Tectonic geomorphology of mountains: A new approach to paleoseismology; Blackwell, Malden, MA, $316 \mathrm{p}$.

Burke K 1996 The African plate; South Afr. J. Geol. 99 341-409.

Canon P J 1976 Generation of explicit parameters for a quantitative geomorphic study of the Mill Creek drainage basin; Oklahoma Geol. Notes 36(1) 3-16. 
Ehlers M, Klonus S and Astrand P J 2008 Quality assessment for multi-sensor multi-date image fusion; In: $C D-R O M$ Proceedings of XXI International Congress ISPRS, 3-11 July 2008, Beijing, China, 499-506.

El Tokhi M 1992 Petrographical, geochemical and experimental studies on the migmatite rocks of Wadi Feiran, Southern Sinai, Egypt; Ph.D. Thesis, Univ. Karlsruhe, Germany.

El-Etr H A, Saleh A S and Abdel Tawab S 1993 Mitigation of flash flood hazards of Wadi Feiran basin, Western Sinai, Egypt; Proc. Inter. Conf. 30 Years Cooper, pp. 309-333.

El-Ghawaby K A, Abdel-Mogheeth M S and Kassem M 1983 Geology and geochemistry of groundwater in Feiran basin; Int. Conf. Groundwater and Man, Sydney 3 35-46.

El-Rayes A E 1992 Hydrogeological studies of Saint Katherine area, South Sinai, Egypt; M.Sc. Thesis, Geology Department, Faculty of Science, Suez Canal University, Egypt.

El-Refaei A A 1984 Geomorphological and Hydrological Studies on El-Qaa Plain, Gulf of Suez, Sinai, Egypt; M.Sc. Thesis, Faculty of Science, Cairo University, Egypt.

El-Refaei A A 1992 Water Resources of Southern Sinai, Egypt; Ph.D. Thesis. Faculty of Science, Cairo University, Egypt.

El-Sayed M H, Abo El-Fadl M M and Shawky H A 2012 Impact of hydrochemical processes on groundwater quality, Wadi Feiran, South Sinai, Egypt; Austr. J. Basic Appl. Sci. 6(3) 638-654.

El-Sayed M M 2006 Geochemistry and petrogenesis of the post-orogenic bimodal dyke swarms in NW Sinai, Egypt: Constraints on the magmatic-tectonic processes during the late Precambrian; Chem. Erde-Geochem. 66(2) 129141.

El-Shafei M K and Kusky T M 2003 Structural and tectonic evolution of the Neoproterozoic Feiran-Solaf metamorphic belt, Sinai Peninsula: Implications for the closure of the Mozambique Ocean; Precamb. Res. 123 269-293.

El-Shamy I Z, El-Ghawaby K A and El-Rayes A E 1989 Geologic factors affecting groundwater occurrences in the basement rocks of St. Katherine area, South Sinai, Egypt; 2nd Conf. Geology of Sinai for Development, Geology Department, Suez Canal University, Egypt.

Gaber A, Ghoneim E, Khalaf F and El-Baz F 2009 Delineation of paleolakes in the Sinai Peninsula, Egypt, using remote sensing and GIS; J. Arid Environ. 73 127-134

Geotz A F, Rock F H and Rowan B N 1983 Remote sensing exploration: An overview; Eco. Geol. 78 573-590.

Geriesh M H 1998 Artificial recharge as an effective tool for augmenting the groundwater resources of Saint Katherine area, South Sinai, Egypt; Proc. 5th Conf. Geol. Sinai Develop., Ismailia, Egypt, pp. 47-67.

Geriesh M H, El-Shamy I Z and Abouelmagd A A 2001 Flash flood mitigation and groundwater augmentating in Wadi Feiran basin, South Sinai, Egypt; Proc. 6th Conf. Geology of Sinai Develop., Ismailia, pp. 303-319.

Ghodeif K O 1995 Hydrogeological studies on east St. Katherine environ, south central Sinai, Egypt; M.Sc. Thesis, Suez Canal University, Ismailia, Egypt.

Grohmann C H, Riccomini C and Alves F M 2007 SRTMbased morphotectonic analysis of the Pocos de Caldas Alkaline Massif, Southeastern Brazil; Comput. Geosci. 33 $10-19$.
GSE (Geological Survey of Egypt) 1994 Geological map of Sinai, Sheet No. 1, Scale 1:25000.

Gupta R 2003 Remote Sensing Geology; 2nd edn, Springer Berlin Heidelberg, 656p.

Hare P W and Gardner T W 1985 Geomorphic indicators of vertical neotectonism along converging plate margins, Nicoya Peninsula, Costa Rica; Tectonic Geomorphology: Proc. 15th Annual Binghamton Geomorphology Symposium.

Harris J R, Murray R and Hirose T 1990 IHS transform for the integration of radar imagery with other remotely sensed data; Photogramm. Eng. Rem. Sens. 56 16311641.

Hassan E A 1997 Geomorphology and hydrogeology of Wadi Feiran area and its surroundings, Sinai-Egypt; M.Sc. Thesis, Geol. Dept., Fac. Sci. Cairo Univ., Beni Suef Branch, 242p.

Issar A and Gilad D 1982 Groundwater flow systems in the arid crystalline province of southern Sinai; Hydrogeol. Sci. J. 27 (3) 309-325.

Jensen J R 1996 Introductory digital image processing: A remote sensing perspective; 2nd edn, Prentice Hall Series in Geographic Information Science, 318p.

Jenson S K and Domingue J O 1988 Extracting topographic structure from digital elevation model data for geographic information system analysis; Photogramm. Eng. Rem. Sens. 54 1593-1600.

Jordan G, Meijninger B M L, Van Hinsbergen D J J, Meulenkamp J E and Van Dijk P M 2005 Extraction of morphotectonic features from DEMs: Development and applications for study areas in Hungary and NW Greece; Int. J. Appl. Earth Observ. Geoinfo. $7163-182$.

Kabesh M, Asran M A and Abdel Rahman E 2013 Mineral chemistry of banded migmatites from Hafafit and Feiran areas, Egypt; Arab. J. Geosci. 6 3669-3681.

Kassem M 1981 Hydrogeological studies in Wadi Feiran, South Western Sinai; M.Sc. Thesis, Geology Department, Faculty of Science, Suez Canal University, Egypt, $181 p$.

Keller E A and Pinter N 2002 Active Tectonics: Earthquakes, Uplift, and Landscape; Prentice Hall, Upper Saddle River, New Jersey, 359p.

Khavari R, Arian M and Ghorashi M 2010 Active tectonics of the South Central Alborz (North Iran); Aust. J. Basic Appl. Sci. 4(6) 969 -993.

Liu L, Zhou J, Jiang D, Zhuang D, Mansary L and Zhang B 2013 Targeting mineral resources with remote sensing and field data in the Xiemisitai area, west Junggar, Zinjiang, China; Remote Sens. J. 5 3156-3171.

Mahran T M, El Haddad A A and Hassan A M 2001 The impact of rift tectonics, paleoclimate and provenance on textural and mineralogical characteristics of syn-rift Miocene sediments of Sidri-Feiran area, southwestern Sinai, Egypt; The 39th Annual Meeting of the Geol. Soc. Egypt, 3-4 Nov., Cairo, Egypt.

Massoud U, Santos F, El Qady G, Atya M and Soliman M 2010 Identification of the shallow subsurface succession and investigation of the seawater invasion to the Quaternary aquifer at the northern part of El Qaa plain, Southern Sinai, Egypt by transient electromagnetic data; Geophys. Prospect. J. 58 267-277. 
Mayer L 1990 Introduction to quantitative geomorphology; Prentice Hall, Englewood, Cliffs, NJ.

McClay K R, Nichols G J, Khalil S M, Darwish M and Bosworth W 1998 Extensional tectonics and sedimentation, eastern Gulf of Suez, Egypt; In: Sedimentation and Tectonics in Rift Basins Red Sea: Gulf of Aden, Springer, pp. 223-238.

Meshref W M 1990 Tectonic framework; In: The Geology of Egypt (ed.) Said R (Balkema: Rotterdam), pp. 113155 .

Mia B and Fujimitsu Y 2012 Mapping hydrothermal altered mineral deposits using Landsat ETM+ image in and around Kuju volcano, Kyushu, Japan; J. Earth. Syst. Sci. 121(4) 1049-1057.

Mohamed L, Sultan M, Ahmed M, Zaki A, Sauck W, Soliman F, Yan E, Elkadiri R and Abouelmaged A 2015 Structural controls on groundwater flow in basement terrains: Geophysical, remote sensing, and field investigations in Sinai; Surv. Geophys. 36(5) 717-742.

Ninomiya Y, Fu B H and Cudahy T J 2005 Detecting lithology with Advanced Spaceborne Thermal Emission and Reflection Radiometer (ASTER) multispectral thermal infrared 'radiance-at-sensor' data; Remote Sens. Environ. 99 127-139.

O'Callaghan J F and Mark D M 1984 The extraction of drainage networks from digital elevation data; Comput. Vision Graph. Image Process. 28 323-344.

Pike R J and Wilson S E 1971 Elevation-relief ratio, hypsometry integral and geomorphic area - altitude analysis; Geol. Soc. Am. Bull. 82 1079-1084.

Ramirez-Herrera M T 1998 Geomorphic assessment of active tectonics in the Acambay Graben, Mexican volcanic belt; Earth Surf. Process. Landf. 23 317-332.

Ramsay J G and Huber M I 1987 The Techniques of Modern Structural Geology: Folds and Fractures, vol. 2, London, $391 \mathrm{p}$

Roth L E and Elachi C 1975 Coherent electromagnetic losses by scattering from volume inhomogeneities; IEEE Trans. Antennas and Propagations 23 674-675.

Sabins F F 2000 Remote Sensing - Principles and Interpretation; New York, W.H. Freeman and Company, 494p.

Schaber G G, McCauley J F and Breed C S 1997 The use of multifrequency and polarimetric SIR-C/X-SAR data in geologic studies of Bir Safsaf, Egypt; Remote Sens. Environ. 59 337-363.
Seleem T A 2013 Analysis and tectonic implication of DEMderived structural lineaments, Sinai Peninsula, Egypt; Int. J. Geosci. 4 183-201.

Shendi E H 1997 On the effectiveness of the VLF-EM method for groundwater prospecting in the basement terrains, Sinai, Egypt; Qatar Univ. Sci. J. 17(1) 143-152.

Shendi E H and Abouelmagd A A 2004 New approach for ground geophysics in the development of groundwater in the basement terrains (A case study from South Sinai, Egypt); Proc. 7th Conf. Geology of Sinai Develop. Ismailia, Egypt, pp. 129-140.

Silva P G, Goy J L, Zazo C and Bardaji T 2000 Faultgenerated mountain fronts in southeast Spain: Geomorphological assessment of tectonics and seismic activity; Geomorphology 50 203-225.

Singh A and Harrison A 1985 Standardized principal components; Int. J. Remote Sens. 6 883-896.

Smith M J and Clark C D 2005 Methods for the visualisation of digital elevation models for landform mapping; Earth Surf. Process. Landf. 30(7) 885-900.

Stern R J 1994 Arc assembly and continental collision in the Neoproterozoic East African Orogen: Implications for the consolidation of Gondwana land; Ann. Rev. Earth Planet. Sci. 22 319-351.

Stern R J 2002 Crustal evolution in the East African Orogen: A neodymium isotopic perspective; J. Afr. Earth Sci. 34 109-117.

Stoeser D B and Frost C D 2006 Nd, Pb, Sr, and O isotopic characterization of Saudi Arabian Shield terranes; Chem. Geol. 226 163-188.

Strahler A N 1952 Hypsometric analysis of erosional topography; Bull. Geol. Soc. Am. 63 1117-1142.

Sultan S A, Mohameden M I and Santos F M 2009 Hydrogeophysical study of the El Qaa Plain, Sinai, Egypt; Bull. Eng. Geol. Environ. 68 525-537.

Tangestani M H and Moore F 2000 Iron oxide and hydroxyl enhancement using the Crosta Method: A case study from the Zagros Belt, Fars Province, Iran; Arab. J. Geosci. 2(2) 140-145.

Thurmond A K, Abdelsalam M and Thurmond J 2006 Optical-radar-DEM remote sensing data integration for geological mapping in the Afar Depression, Ethiopia; J. Afr. Earth Sci. 44 119-134.

Wachs D, Arad A and Olshina A 1979 Locating groundwater in the Santa Catherina area using geophysical methods; Ground Water 17(3) 258-263. 